AN ANALYTICAL SURVEY OF POPULATION

AND DEVELOPMENT IN BANGLADESH

W. Brian Arthur

Geoffrey McNicol1

September 1978

Professional Papers are not official publications of the International Institute for Applied Systems Analysis, but are reproduced and distributed by the Institute as an aid to staff members in furthering their professional activities. Views or opinions expressed herein are those of the author and should not be interpreted as representing the view of either the Institute or the National Member Organizations supporting the Institute. 



\title{
An Analytical Survey of Population and Development in Bangladesh
}

\author{
W. BRIAN ARTHUR \\ GEOFFREY MCNICOLL
}

It is helpful at times to stand back

from a subject and try to pull together the various strands of knowledge that have accumulated about it. This is our purpose in the present study of population and development in Bangladesh. In writing this survey we present more than a collection of facts and figures. Throughout, we are concerned with analysis of the forces and realities behind the data, with trying to make sense of the economic and demographic processes that lie beneath Bangladesh's development problems.

We bring to the study no new evidence or data; rather, we marshal existing knowledge as a base for analyzing population and development issues and assessing development alternatives. Because of the sometimes weak and fragmentary nature of this knowledge in the case of Bangladesh, the picture that emerges is in places blurred and speculative. But it is consistent enough on the whole to allow us to draw some broad conclusions. A country study might be expected to forecast trends and offer prescriptions for policy. Here we do neither. Our interest is more to locate the particular economic, demographic, and social forces that seem likely to influence the style of future development and set its bounds. Rather than propose specific measures in a country where government has, at best, a limited impact on local realities, we keep policy discussion at the level of overall strategy.

Economic and demographic behavior is usually seen in either macro or micro terms. National statistics are the outcome of decisions at the individual level, and individual incentives in tum are set by aggregate 
conditions. Particularly in Bangladesh, however, we must seek much of our understanding at a level between these extremes-in the details of social organization and local institutions. We spend considerable time discussing the Bangladesh situation at this intermediate level. It is here that problems faced by government programs, prospects for rural change, and present adverse patterns of demographic behavior can best be explained.

We begin with a view of Bangladesh at the aggregate level, examining where the country stands and how it came to that position. In the second and third sections we shift our focus to the local level, investigating how social organization affects and is affected by the local economy, and how these in turn influence individual incentives and demographic behavior. A final section assesses prospects and possibilities for future development in Bangladesh.

\section{The Bangladesh}

\section{Setting}

The economic circumstances of Bangladesh are as familiar as they are precarious. Per capita incomes are among the lowest in the world; less than 15 percent of the adult population has had five or more years' schooling; farm holdings are small and fragmented, with a growing proportion (now perhaps a third) of rural households landless; the country has not been self-sufficient in food for over two decades; nutritional levels are believed to be inadequate for half the population. Demographic conditions, too, are extreme. Crowded into a country a third the size of California are some 85 million people; over 75 million of them live in the countryside, making Bangladesh the most densely populated rural country in the world. Marriage takes place at a very young age and is all but universal; total fertility, the average number of children born to a woman surviving through her reproductive years, may be as much as seven; and death rates are still high, though perhaps half the level of 25 years ago. Even optimistically, the population growth rate cannot be lower than 2.5 percent per year, a level that would double the population in under 30 years.

What is interesting about this litany of grim statistics is not that life in Bangladesh is at a bare subsistence level but that economic and demographic behavior worsening these conditions can persist in the face of such circumstances and may indeed be fostered by them. In what follows we investigate how and why this is so.

\section{Colonial Past}

For most of the last four centuries, as Bertocci (1976) has remarked, the setting for Bangladesh's economic history has been "the control of East 
Bengal by structures of state power whose decision-making centers have been outside the region." For some 200 years following Bengal's formal incorporation in the Moghul empire in 1576, the region seemingly maintained a relative prosperity that, to judge from travelers' reports, dated back to the middle ages. ${ }^{1}$ Rice cultivation dominated then as it does today, but a diversified agriculture and a successful local silk and cotton industry were the basis of a vigorous export trade.

In the late eighteenth century, Moghul power was gradually yielded to the British East India Company, with formal British administration following in 1857. Company dominance coincided with a rapid decline in local industry, tracing the familiar pattern of colonial territories in the Industrial Revolution but here hastened by a series of natural disasters. From being a balanced agrarian economy the region was converted into a raw-materials base for British industry. Local textile manufacturing virtually ceased in competition with machine-made yarns and fabrics, while specialization in export crops was emphasized-indigo and safflower in the early $1800 \mathrm{~s}$, later jute and tea. ${ }^{2}$ Under this deindustrialization, the population of the main commercial centers declined. ${ }^{3}$

Creation of Pakistan in 1947, accompanied by the violence and massive migrations of Partition, put an end to official colonial rule. But for East Bengal (now East Pakistan), the new arrangements merely transferred power from Delhi to Karachi, creating in effect a new colonial relationship that did little to aid development in the region. Jute milling, previously concentrated around Calcutta and cut off in the Partition, was reestablished in Dacca, but little else happened to fulfill the early promise of economic progress. Pakistan's development program was ill suited to the agrarian needs of its East Wing. Agriculture stagnated in the 1950s, picking up only slowly in the 1960s with the first stirrings of the Green Revolution. Output failed to stay abreast of population growth: Domestic demand for rice began to shrink the area available for jute cultivation, and even so, by the late 1960s East Pakistan was importing about 10 percent if its food requirements. By this time, when moves were finally made to remedy some of the East-West inequities, it was too late to avert civil war.

In 1971 the new nation of Bangladesh emerged, following a ninemonth struggle for independence that took as many as half a million lives, displaced at least temporarily a tenth of the population, and saw the loss of a significant part of the country's physical capital and managerial talent.*

One continuing reality lay behind these changing regimes over the two centuries preceding independence: Much of the region's agricultural surplus was removed, leaving little available for investment within it. Under the Company and the formal British administration, this was the deliberate outcome of colonial policy, rationalized in the values of empire. Bengal had a significant grain surplus, which the British managed 
to extract by tightening the loose procurement system they inherited from the Moghuls. Under Pakistan in the 1950 s a shrunken agricultural surplus could still be removed, but now the mechanisms were different. Investment funds were allocated predominantly to promote industrial development in Pakistan's West Wing, and the overvalued currency, maintained so as to favor capital-goods imports, penalized the jute-export economy in the East. This was largely the result of a strategy of industrialization through import substitution, popular in the 1950 s, that promoted industry at the expense of agriculture. But in Pakistan the sectoral imbalance typically created by such a strategy coincided with the country's EastWest division. Much of the value of the East's jute exports was in effect transferred to the West. ${ }^{5}$

With the steady removal of potential investment resources under a succession of colonial regimes, the region had little chance to develop its economic base. Indeed, growth of the rural economy in the years from the establishment of jute cultivation in the mid-nineteenth century through the 1960s could well be described by the term that the Dutch economist J. H. Boeke used of Java: static expansion. The economy steadily enlarged itself, but its underlying structure remained the same. Bangladesh today retains essentially the same economic base that had been established by the 1850s: cultivation of rice, jute, and a few other crops, and export of agricultural goods, mainly raw jute and manufactured jute products. Even though total output is larger, so too is population, with the result that the important qualitative indexes-crop yields, labor productivity, and real incomes-have shown slight improvement or even have worsened over the years. ${ }^{\circ}$

If Bangladesh was left little in the way of useful economic structure from its colonial era, neither did it inherit a strong administrative framework. Under the "Permanent Settlement" of 1793 the British created a de facto landlord class, the zamindars, charged with collecting revenue. ${ }^{7}$ These in turn brought into being a multilayered hierarchy of tenants and undertenants to squeeze revenue upward from the cultivator at the bottom. Authority at the village level came to rest in the hands of these middle men, supplanting an already weak system of village self-government and acting in lieu of a formal administrative structure. It was a system designed to extract surplus, which it did easily, though with considerable leakage; but it left the British with minimal control or even information below the level of the zamindars. Government reports in the nineteenth century speak of "administrative starvation" in East Bengal, a truncation of lines of administration even by the usual British colenial pattern of indirect rule. This condition persisted despite a succession of efforts to fill the institutional gap. ${ }^{8}$ In the first decade of Pakistan rule local government was again neglected. Only with the introduction in 1959 of the "Basic Democracies" system, which set up elected and ap- 
pointed councils at various administrative levels, did the outlines of a formal local government structure begin to take shape. But the realities were disappointing. The national government's capacity to influence events at the local level remains limited today.

In sum, then, Bangladesh inherited little from its colonial era that could be used as a basis for development. Two centuries of underinvestment left an economy narrowly based, rural, and static. It also left a legacy of underadministration, so that when there was finally a commitment to rapid development, the national government had limited capability to promote needed changes at the village level. The main challenge of creating an appropriate framework for national development has still to be met.

\section{Environmental}

\section{Conditions}

Crucial to understanding much of what happens in Bangladesh are its unique environmental circumstances. ${ }^{9}$ The country lies on the delta of the Ganges, Brahmaputra, and Meghna rivers, an immense system of tributaries and distributaries draining the central and eastern Himalayas and the foothills of Assam. With the exception of the Chittagong Hill Tracts adjoining the borders with India and Burma in the southeast and some small areas in the northeast, most of the country is less than 15 meters above sea level. In normal years a third of the cultivated area is one meter or more under water at the peak of the monsoon floods. The silt deposited during this seasonal inundation maintains the high soil fertility, making possible the extreme rural-population densities that characterize the active delta areas (see Figure 1).

Siltation has another, less favorable effect, however. It steadily raises the beds of the rivers and thus renders their courses unstable. There are both short-run and long-run consequences. In each monsoon some banks are eaten away, while new land is built up elsewhere-sometimes only to disappear again in a future season. Quite extensive land areas may be involved in these year-to-year shifts, with a large impact on the loca! economy. Over the centuries there has been a steady eastward shift in the active delta region, leaving major parts of the western districts (the so-called moribund delta area) no longer flushed and renewed by the annual flooding. This trend has been marked by spectacular shifts in some of the main channels-most recently in the late 1700s and early 1800 s, when the Brahmaputra changed course to form the Jamuna River and the junction between the Ganges (Padma) and Meghna rivers was first formed.

With a very dense population living under marginal geographic conditions, it takes only slight changes to produce disasters. Shifting river 
Figure 1

Bangladesh

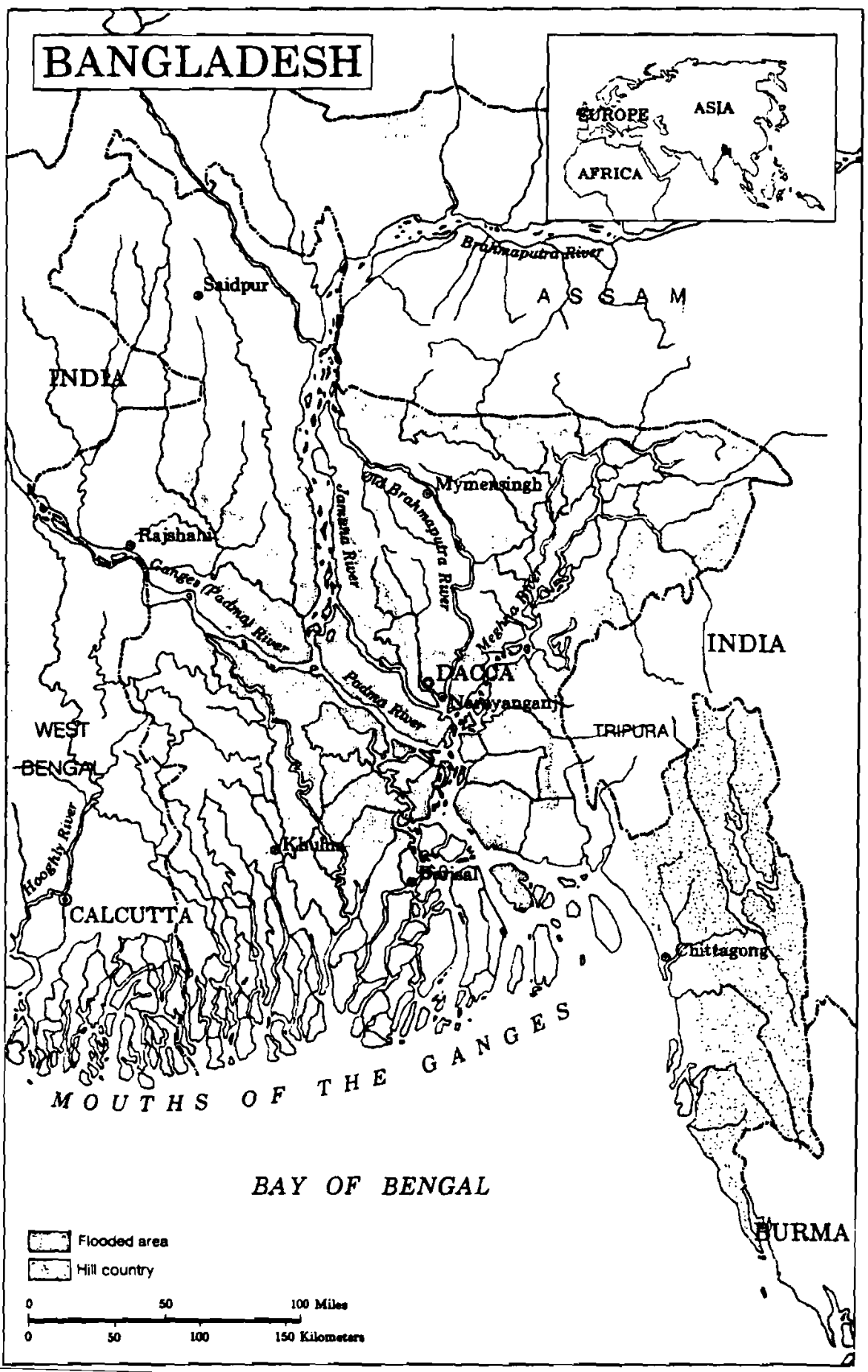


courses are only one of the natural hazards facing Bangladesh. Variations in the timing and amount of the monsoon rains can cause severe crop damage and consequent local famine. With multiple cropping and the contracted growing seasons of some of the new crop varieties, these fluctuations become even more critical. Along the southern coast in the tidal areas, salinity poses a constant threat to agriculture. Cyclones are common in the Bay of Bengal and have accounted for much loss of life over the years through excessive flooding. The tidal waves (bores) that sometimes accompany them have been a major cause of destruction on the islands in the delta mouth. Table 1 charts the worst of the natural disasters over the last two centuries, together with the man-made calamities of more recent years.

Table 1

Major Disasters in Bangladesh in the Last 200 Years

\begin{tabular}{|c|c|c|}
\hline Year & Event & Casualties \\
\hline $1769-76$ & Great Bengal Famine & $\begin{array}{l}\text { "Eliminated almost a third of Bengal's } \\
\text { population" (A. Ahmed, 1962, p. 140), } \\
\text { although impact was less severe in East } \\
\text { Bengal (N. Ahmad, 1968, p. 327) }\end{array}$ \\
\hline $1784-88$ & $\begin{array}{l}\text { Floods and famine; } \\
\text { radical shift in course } \\
\text { of Brahmaputra (1787) }\end{array}$ & Unknown (N. Ahmad, 1968, pp. 33, 101) \\
\hline $1873-74$ & Famine & Unknown (A. Ahmed, 1962, p. 141) \\
\hline 1876 & $\begin{array}{l}\text { Bakarganj Cyclone and } \\
\text { tidal wave }\end{array}$ & c. 400,000 deaths (N. Ahmad, 1968, p. 51) \\
\hline $1884-85$ & Famine & Unknown (Bhatia, 1967, p. 164) \\
\hline 1897 & Chittagong Cyclone & c. 175,000 deaths (N. Ahmad, 1968, p. 51) \\
\hline $1918-19$ & Influenza epidemic & $\begin{array}{l}\text { c. } 400,000 \text { deaths (M. R. Khan, } 1972 \text { b, } \\
\text { p. } 384 \text { ) }\end{array}$ \\
\hline 1943 & Bengal Famine & $\begin{array}{l}\text { 2-2.5 million deaths (A. Ahmed, } 1962 \text {, } \\
\text { p. } 141 ; \text { M. R. Khan, 1972b, p. 384) }\end{array}$ \\
\hline 1947 & Partition of India & $\begin{array}{l}\text { Unknown; total deaths in Partition } \\
\text { C. one million, but most were in West } \\
\text { (Davis, 1951, p. 197) }\end{array}$ \\
\hline 1970 & Cyclone and tidal wave & 200,000-500,000 deaths (L. C. Chen, 1973) \\
\hline 1971 & War of independence & $\begin{array}{l}\text { c. } 500,000 \text { deaths (Curlin, Chen, and } \\
\text { Hussain, 1976, p. 31) }\end{array}$ \\
\hline 1974 & Famine & $\begin{array}{l}\text { Officially c. } 30,000 \text { deaths (Majlis, 1977), } \\
\text { although some estimates are much higher } \\
\text { (e.g., } 500,000-\text { Baldwin, } 1977 ; 80,000 \text { in } \\
\text { Rangpur district alone - Haque et al., } \\
\text { 1977) }\end{array}$ \\
\hline
\end{tabular}


Environmental circumstances-in particular, duration and depth of flooding-largely dictate agricultural possibilities. They govern where double cropping is feasible, where paddy can be transplanted rather than broadcast, and where short-stemmed varieties rather than deep-water floating rice can be grown-all factors that greatly affect land productivity. In the delta areas that are flooded no more than a meter or so, two rice crops are typically possible: one ("autumn rice") harvested early in the monsoon, the other ("winter rice") transplanted after the floods begin to recede. Jute competes with the former crop. In more heavily inundated areas, only a single crop can be grown: either floating rice, able to keep abreast of rising floodwaters to a depth of 5 or 6 meters, or, where flooding is even deeper, dry-season "summer rice." A single rice crop is also all that is possible in the areas of decaying rivers and poor drainage in the western and northwestern districts, where long fallow periods have traditionally been required. Finally, in the hills near the eastern borders shifting cultivation is still practiced. ${ }^{10}$

Agriculture would be less tied to local conditions if modern water control were more widely available. Mastery of the environment is still at a relatively primitive level, however. The hazards of minor year-to-year variations in weather patterns and seasonal flooding can be countered by individual or community effort-building mounds and levees, drilling wells, digging and dredging irrigation channels, elevating cowsheds on bamboo stilts, and so on. But the population is nearly defenseless against the recurrent larger vagaries of wind and water. Real mastery of the delta would call for interventions of a much larger magnitude. As yet, however, few large-scale projects have been undertaken. ${ }^{11}$ Ironically, the largest effort in the region to modify environmental conditions, the recently completed Farakka Barrage, dams the Ganges just on the Indian side of the border and has the potential to seriously injure the agricultural ecology of western Bangladesh. ${ }^{12}$

\section{Settlement}

and Survival

We turn next to the human ecology of Bangladesh. The region's demographic history parallels that of the subcontinent as a whole. ${ }^{13}$ The recorded part of this history spans barely a century, from the first census covering Bengal in 1872. Already at that time there were 23 million people counted in the area that is now Bangladesh. Up to about the mid1920 s the story is one of slow population growth against environmental and technological constraints, interrupted by large-scale setbacks. ${ }^{14}$ After that, mortality receded more or less steadily, a decline halted only by the Bengal Famine of 1943 and the disturbances of Partition. As a result population growth accelerated sharply: In the 1930s for the first time it 
exceeded 1 percent annually over a decade, and recently it has reached 2.6 percent per year.

The mortality decline over the last 50 years has reduced the death rate from above 40 per thousand to a level of about $20 . .^{15}$ Various factors have contributed to this drop, their relative weights not fully agreed upon: fewer famine-related deaths as transport and communication systems developed and government relief measures became more effective, ${ }^{16}$ some improvements in public health, the introduction of specific treatments for epidemic diseases, and lessened virulence of some of the diseases themselves (notably plague). In cause of death, the most important declines have probably been in the incidence of smallpox, cholera, and malaria-the first now eliminated, the others substantially under control (although malaria shows some indication of resurgence). ${ }^{17}$ But in spite of these improvements, the mortality level is still high by contemporary standards, even among developing countries.

There has been no comparable secular trend in fertility. Recent estimates mostly put the birth rate in the range of 45 to 50 per thousand, a rate probably not much lower than a century ago. ${ }^{18}$ Migration has been sporadic, with a large net exodus at the time of Partition and again in 1971, but on average has little impact on population growth. ${ }^{19}$ An estimated population trajectory and a possible sequence of crude birth rates for Bangladesh over the last century, based on official (Bureau of Statistics) data, are sketched in Figure 2. The detailed pattern may be debatable, but there is little doubt that the broad features shown are correct.

When we look more closely at the demographic picture, we see population growth linked tightly to local environmental conditions. Two processes are at work. First, wherever new technology or resources appear, settlement expands to take advantage of them. Population growth, as it were, follows the contours of local economic opportunity. Second, the pressures and momentum of continued population growth sooner or later exhaust whatever "slacks" these opportunities provide; people are forced to seek and exploit whatever other local means of subsistence they can find.

The first process can be seen in the expansion of the jute industry in the late nineteenth century. Jute cultivation, concentrated in the central, annually flushed part of the delta, created an income that could finance rice purchases from the western districts and later from abroad. Census figures since 1872 record slow but steady population growth in this core area, whereas the rest of the country showed comparatively little change. ${ }^{20}$ Migrants flowed in, attracted by the small but sustained regional surplus; and the marginal improvement in the local economy may also have lowered mortality.

Similarly, the beginnings of significant technological change in agriculture in the last 10 to 15 years present another kind of opportunity. 
Figure 2

Outline of Population and Vital Rates,

Bangladesh, 1872-1974

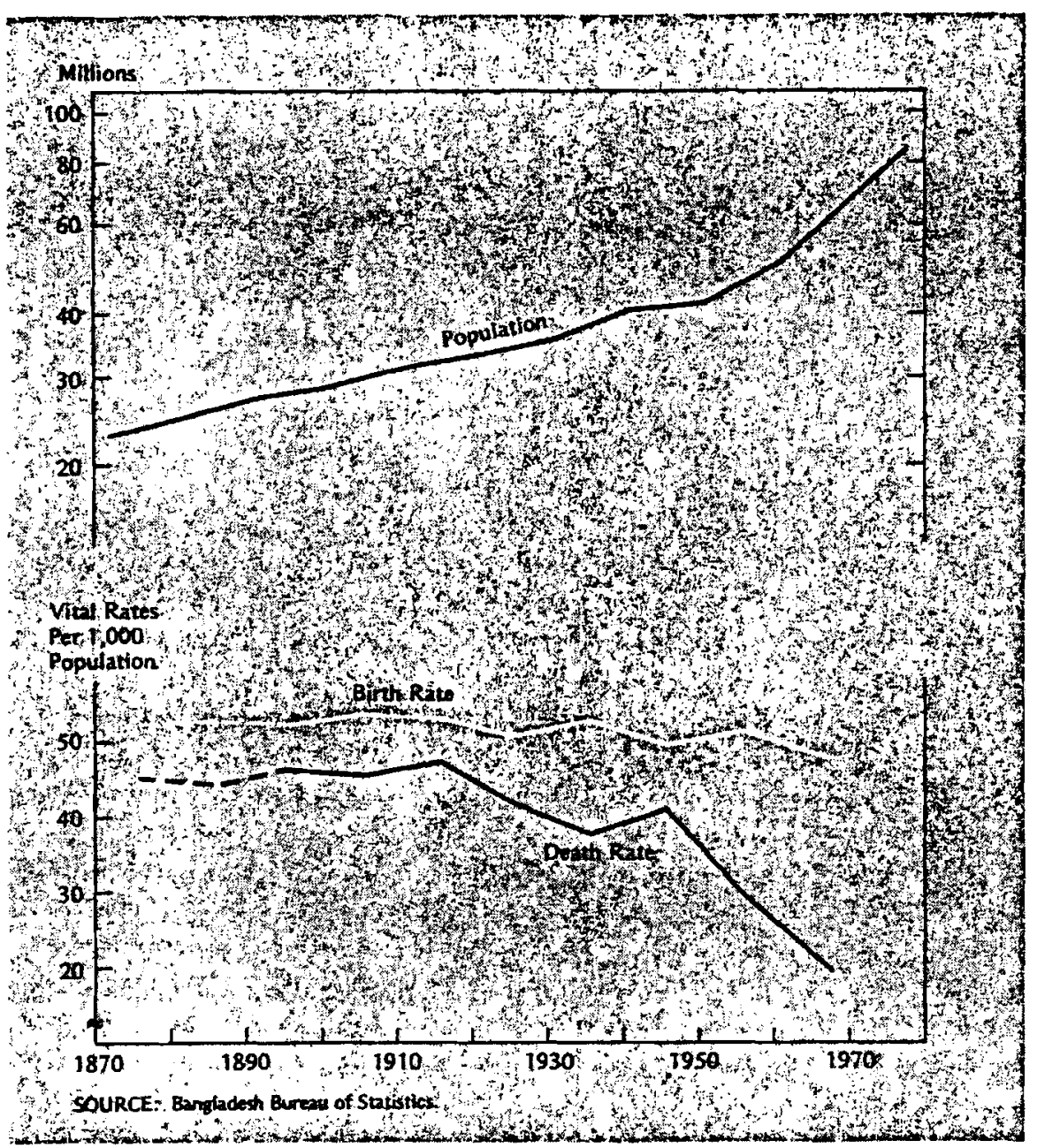

With the increased use of irrigation and chemical fertilizers in the past decade, high-yielding, fertilizer-responsive rice varieties have been replacing traditional varieties, particularly in the districts along the westem border (Dinajpur, Rajshahi, Kushtia, and Jessore). These areas recorded relatively high growth rates in the 1961-74 intercensal period.21

Even small-scale opportunities attract population. People are quick to settle on the char lands in the delta mouth-land that appears and as quickly can disappear with the shifting patterns of siltation.

Opportunities do not come along in a steady stream, however, and as population growth continues in any locality, the slacks they create are 
progressively exhausted. But the demographic processes at work do not reverse at that point. Fertility does not adjust downward, nor does mortality easily rise again. Migrants once settled tend to stay. The result is a downward pressure on standards of subsistence as demographic inertia presses growing numbers against the limits of productive possibilities. Thus we see cultivated land expanded to its fullest extent, with significant areas that are in production lying in extremely hazardous zones. Fishing, too, is heavily exploited in inland waters, though less so in the Bay of Bengal. The influx of destitute villagers into the cities-some just for short periods until rural conditions improve again, others with nothing to go back to-is another manifestation of this Ricardian process of increasing marginality.

Thus, not only does population settlement follow environmental opportunities, but the inbuilt inertia of demographic processes exhausts these over the years and pushes environmental limitations as far as they will stretch. But limitations reached in the short term may not hold up over a longer time. Overexploitation can set into motion long-run forces of ecological degradation that are difficult to reverse. An important past instance was the building of embankments, where local safety from flooding was often bought at the cost of accelerating river decay over the long term. More recently, population growth in the largest remaining forest area of Bangladesh, the Chittagong Hill Tracts, has been shortening the fallow periods in shifting cultivation, leading in turn to serious soil erosion. And the current technological improvements in agriculture, entailing large applications of fertilizer and pesticides and greater crop specialization, may very well have their own adverse effects on the delta ecology, as yet barely visible. ${ }^{22}$

Independence

and After

With political independence barely seven years old, where does the country now stand and what are its economic prospects?

The first years of independence were difficult. Bad harvests in 197273 were followed by damaging floods in the summer of 1974. International terms of trade worsened considerably: Prices of foodgrains, petroleum, fertilizer, and cement rose sharply, while jute stagnated. Inflation, falling real wages, labor unrest, and political instability added to the troubles. ${ }^{23}$ Two years of good harvests and stable government put the initial setbacks into a better perspective. But even allowing that it takes time for a new country to get proper control of its economy, it is clear that Bangladesh faces difficult problems in the period ahead.

What is the outlook for the industrial sector? The country has sizable reserves of natural gas, with exploration still at an early stage (and barely 
begun offshore). The largest presently known field (Bakhrabad, discovered in 1968) may alone justify construction of a liquification plant. If so, liquified natural gas could rapidly become Bangladesh's second largest source of export earnings, with the possibility before long of overtaking jute. Natural gas can also support a fertilizer industry, producing for both domestic use and export. A growing domestic market may stimulate production of a wide range of consumer goods and some items of capital equipment (agricultural implements, pumps, and so on), and improving relations with Pakistan may reopen that market for "soft" manufactures. Perhaps even assembly plants for reexports on the South Korea-Taiwan model might be developed, although this seems unlikely to occur on a scale large enough to have more than a minor impact. ${ }^{24}$

In the agricultural sector, hopes rest on the new high-yielding crop varieties and their accompanying technology-in particular, better water control. As is often remarked, rice yields in Bangladesh are only a third of Japan's (although they are in line with those of India and most of Southeast Asia). A World Bank analysis undertaken in 1971 concluded that with presently known techniques, together with adequate supplies of fertilizer and other inputs and proper irrigation and drainage, rice production could be quadrupled by the end of the century. Even without costly, large-scale water control projects (i.e., by relying chiefly on tubewells and low-lift pumps), a trebling of output was considered feasible.25 But between these possibilities and today's realities stand major obstacles. First, it is doubtful whether the new technology will be adopted under circumstances at all close to optimal. Not only must inputs be correctly combined with fairly precise timing over the crop cycle, but the technology requires a degree of local infrastructure-credit, extension services, distribution, cooperative water arrangements-not easily put together under present social arrangements. Second, many traditional crops, such as jute and floating rice, have as yet no high-yielding counterpart. Yield increases have occurred mostly in areas that grow the relatively small "summer rice" crop. Third, diffusion of the new technology cannot go faster than the speed with which pumps, fertilizer, and other inputs become available. Not surprisingly, then, although high-yielding varieties have been adopted rapidly in some districts over the past decade, results on a national level have so far been disappointing. ${ }^{26}$ Writing in 1975, Noazesh Ahmed (1976, p. 19) concluded that "irrigation facilities and the input package programmes so far extended have had little effect on the national production of rice. The higher rice production in the country still depends mostly on good weather conditions."

In this brief account we have seen that Bangladesh at independence inherited a largely static and iraditional rural economy with a small industrial base. A densely settled population, growing rapidly over the last few decades, meshes tightly with a hazardous natural environment. The 
local administrative system is weak, limiting the national government's ability to influence events at the local level. Important opportunities for industrial growth exist, but because of the economic dominance of agriculture, any hope of rapid change necessarily rests on progress in the rural sector. Here we have a recognized technological path to follow, although one that has severe obstacles along the way.

\section{The Local Context \\ of Development}

Underlying the rural economy and governing much of its performance is a complex local social system. In this section, we ask how this system works and how it is supported, and examine the ways in which it promotes or impedes various kinds of social change. In shifting our focus from the national to the local level, we are led into territory equally unfamiliar to the demographer and the development planner, but an area in which both the economic and demographic future of Bangladesh is likely to be decided.

Dynamics

of Landholding

Local organization in rural Bangladesh is closely tied to the ownership of land. Land, in a country with few other productive assets, bestows status, power, and above all security. Although in good years income from wage labor can support a family, over longer periods, with a saturated labor market, it is a poor guarantee. Only ownership of land, or usage rights to it, provide a long-run sureness of access to the local social product. Not surprisingly, then, wealth and social standing in rural Bangladesh are measured in terms of landholding. ${ }^{27}$

With virtually no farms that are large in absolute terms, small variations in landholding can lead to marked differences in social class. Divisions are somewhat arbitrary, but we might distinguish four classes of ngricultural families. ${ }^{28}$ Those who control about 3 hectares or more constitute the rural elite-5 percent of families with roughly 20 percent of the agricultural land. These are the landlords and the surplus peasants. Beneath them are the middle peasants, those with about 1 to 3 hectaresroughly 25 percent of families in agriculture. Many of these are both landowners and tenants. Next in standing are marginal peasants with less than 1 hectare, including the poorest tenant farmers and sharecroppers. Finally, at the bottom of the scale are landless agricultural workers, forced to rely on agricultural wage labor and whatever other sources of income they can find. These last two categories cover more than twothirds of the agricultural population. Subsistence for them in all but the 
best of times depends on relations with the larger landowners to help them secure wage employment.

Declining landholding lies behind much of the present rural impoverishment. The actual dynamics of landownership are complicated, but the main processes are closely tied to population growth and are worth looking at in some detail.

If population were stationary, land could be turned over from father to son in a fairly constant pattern over the generations. Where population is growing rapidly, as in Bangladesh, patterns must change, and there are a limited number of possibilities for accommodation: more land brought under cultivation; more farms on land already in use; more people on existing farms; or more people landless. Each of these options appears to have been taken in Bangladesh.

Historical data on landholding are hard to come by, but it appears that in the early part of the century the growing population was accommodated by expansion of cultivated land and by an increase in the number of farms (as land was increasingly subdivided by inheritance). In the last 20 to 30 years these two possibilities have largely been exhausted. By the early 1950s expansion of cultivated land had virtually ceased; and as farm sizes grew smaller through constant division, holdings were increasingly pushed below subsistence level-the size needed to support a family's consumption. ${ }^{29} \mathrm{~A}$ limit to the multiplication of smaller and smaller farms was in effect reached. Below a certain subsistence size, families were likely to fall into debt in a poor season, entering a downward spiral that frequently ended with the loss of their holdings to the more affluent. Population growth, no longer able to be accommodated on increasing numbers of smaller farms, added instead to the landless and to the numbers per farm.

The figures bear out this sequence. As Table 2 indicates, numbers of smaller farms have not increased in the last 20 years; in fact, the size distribution has been almost constant.. ${ }^{30}$ Landlessness, on the other hand, has greatly increased. The trend is strikingly evident in recent surveys, which show the landless agricultural population growing from about 15 to 20 percent in the early 1960s to between 30 and 35 percent a decade later. ${ }^{31}$ Simultaneously, the average numbers per farm have risen as well. During the 1961-74 intercensal period, the increase in the agricultural labor force was roughly 5 million and that of landless agricultural workers perhaps 3.5 to 4 million, leaving more than a million workers, together with their dependents, added to the population on existing farms. ${ }^{32}$

The implications of these processes are several. Obviously, faced by the prospect of losing land, individual families have less security. The threat of landlessness hangs over the great majority of landholding families. Purchasing land or holding on to what one has becomes an overriding concern. 
Also, the increasing numbers of people per farm create pressure to seek other sources of income. Detailed studies of individual farm families reveal an astonishing range of income-generating activities in addition to farming. One analysis of a village economy in a national-income format found less than half of village income attributable to cultivation, and only two-thirds to all of agriculture. ${ }^{33}$ For the poorer peasants petty trading, fishing, and handicrafts can supplement wage labor. The better-off are often active in such small businesses as marketing agricultural products, distributing inputs, and moneylending. ${ }^{34}$

Table 2

Distribution of Farm Area

by Number and Size of Farms (Operational Holdings), Bangladesh, 1960, 1968, and 1974

\begin{tabular}{lrrr}
\hline $\begin{array}{l}\text { Percent of Farms } \\
\text { Ranked by Size } \\
\text { (Quintiles) }\end{array}$ & \multicolumn{3}{c}{ Percent of Farm Area Operated } \\
\cline { 2 - 4 } & 1960 & 1968 & 1974 \\
\hline First (bottom 20\% of farms) & 2.3 & 3.0 & 1.6 \\
Second & 8.4 & 8.3 & 3.4 \\
Third & 14.3 & 13.3 & 14.4 \\
Fourth & 21.8 & 22.4 & 25.6 \\
Fifth (top 20\% of farms) & 53.2 & 53.0 & 55.0
\end{tabular}

SOURCE: Alamgir (1975), p. 268. Data compiled from 1960 Agricultural Census, 1968 Master Survey of Agriculture, and village surveys taken in 1974 by Bangladesh Institute of Development Studies.

As a further consequence, growing numbers of landless put an increasing pressure on the already strained labor market. We noted earlier that real wages have fallen substantially in recent years. This trend could be ameliorated somewhat by the new agricultural technology, which is modestly labor absorbing, but offsetting this hope is the growth of the farm population itself. Farmers are more likely to employ their own family members before they hire others. ${ }^{35}$ Finally, as people are pushed off farms, out of ownership into wage labor, agriculture is slowly becoming commercialized. Small-scale peasant ownership and localized labor markets are giving way to an economy based on impersonal employer-employee relationships, a primary source of change we will look at shortly. ${ }^{30}$

\section{Social Organization}

in a Changing Society

The preceding picture of a skewed distribution of access to the rural economy is a major part of the Bangladesh reality. But access is not so 
simply determined. As in any traditional society, ties of kinship, patronage, and neighborhood may cut across landholding, serving to strengthen or weaken an individual's claim on the social product and to modify his sense of risk or security.

The pattern of rural social organization at the local level is intricate. People scattered through various horizontal layers of landholding classes are bound together, sometimes strongly, sometimes casually, into groupings of several different kinds. Table 3 gives a schematic summary of the more important of these, achieving comparative simplicity of description at the cost of blurring many fine distinctions and ignoring local variations. ${ }^{37}$ Besides those groupings mentioned, there are divisions along religious lines (the Hindu minority is separate in many respects), by occupation (the residue of caste, with modern status rankings superimposed), and by length of residence in a particular locality. It is sufficient here, however, to pick out the more powerful organizing forces.

Kinship ties at several levels enmesh individuals in a range of obligations and in turn help to distribute the burden of risk. The nuclear or patrilineally extended family is the basic social and economic unit of Bangladesh society. Beyond his immediate household, a person has welldefined duties to his bari (homestead) and somewhat weaker ties to larger, kin-based groups (paribar and gusthi). For example, the bari often operates as a corporate entity with land held in the name of its head, who exercises patriarchal control over members. ${ }^{38}$ Paribar and gusthi tend to dominate in such matters as selection of spouse and negotiation of dowry or bride-price, the upbringing of children, and disposal of assets. These extended family and lineage groups have more signifcance among the bigger landowners. For families with no land or only a house compound, there is little economic rationale for emphasizing relations with close but equally impoverished kin.

For families with a tenuous place in the economy, alliances with leading surplus farmers in patronage groupings (shamaj, reyai) have much to offer. In exchange for allegiance the small landholder or landless worker may receive preferential employment, some support in bad years, seasonal credit, and other benefits. The leader in turn obtains a following to support him in local elections and disputes and, obviously, a sense of importance. The nucleus of a patronage group consists of the leader and his close relatives; wider membership typically comes from adjacent households within the village. (A village may contain several such groups.) The functions of patronage groups vary somewhat district by district. In some they are purely political; in others quasi-official functions-part ceremonial, part judicial-are also present. Membership may change over time, and not all families necessarily belong to any group of this sort. In at least some villages there are also informal factional divisions separate from shamaj groupings (or occasionally within them). 
These factions (dal), often at odds with each other, have a more fluid, even shadowy presence that is not openly discussed with outsiders, but may form an important part of local political reality. ${ }^{39}$

Natural villages or hamlets, the basis of rural settlement and local allegiance in much of Asia, are weak in Bangladesh-a fact that has important consequences for development. The natural village (gram) is socially defined, and residents have a clear perception of its territorial boundaries; but these units tend to have no corporate features, little cohesive identity, and only a residual degree of solidarity. ${ }^{40}$ One writer has observed: "A man's duties are, in order, to his own family (bari), then toward his paribar, then to his gusthi and then to his village." 1 Settlement patterns are partly responsible: In land subject to extensive seasonal flooding, small groups of homesteads are clustered on raised ground (often mounds or levees) built up from surrounding flood plains; hence, dispersed or linear settlements rather than nucleated villages are the rule. ${ }^{42}$ But the relative lack of function of villages in the society can also be traced to the colonial failure to provide effective local administration. As a consequence, village life is segmented. A man may reside in one village, attend a mosque in another, patronize a market in a third, and cultivate plots of land in any or all of them. For adjudication of minor disputes he may call on the head of his gusthi or on the leader of the shamaj to which he belongs; for assistance in ploughing or harvesting he may turn to other members of his paribar or to wage labor from distant villages.

Territoriality is not completely missing from Bangladesh social organization, however. The subvillage neighborhood cluster, the para, is sometimes a cohesive social unit, although it has little explicit role at present. And as we have seen, patronage groupings also have a kind of territorial basis, albeit a fluid one. But for the most part, functions usually ascribed to the village community in peasant society are filled in rural Bangladesh by a variety of nonresidential and overlapping groups with more or less specialized concerns-religious, political, economic, and so on.

From this brief description, kinship and patronage ties stand out as the most powerful organizing forces in rural society. These two traditional forces together characterize the local system. They act as a simple, nonmarket distributive mechanism, channeling access and security downward; and, by binding together people of various social levels, they have tended to diffuse any strong manifestation of class. They have given the system a high measure of stability.

Under the twin pressures of population growth and increasing commercialization, there are signs that both kinship and patronage bonds are weakening. ${ }^{43}$ As population grows, the kinship-patronage distributional system may become overloaded: Assets are diluted through the subdivision of land, supporters' needs grow, and numbers of people on the 


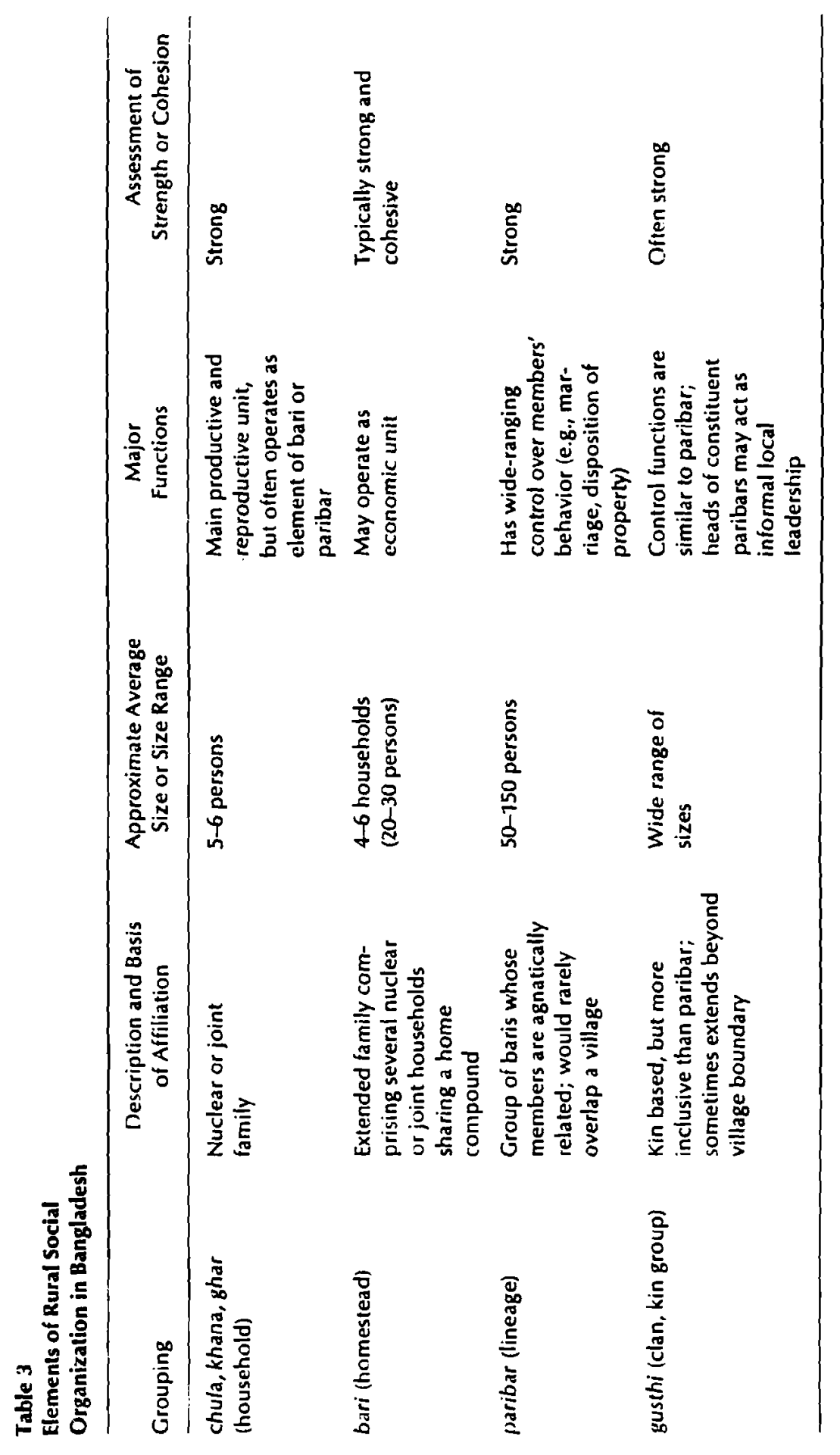




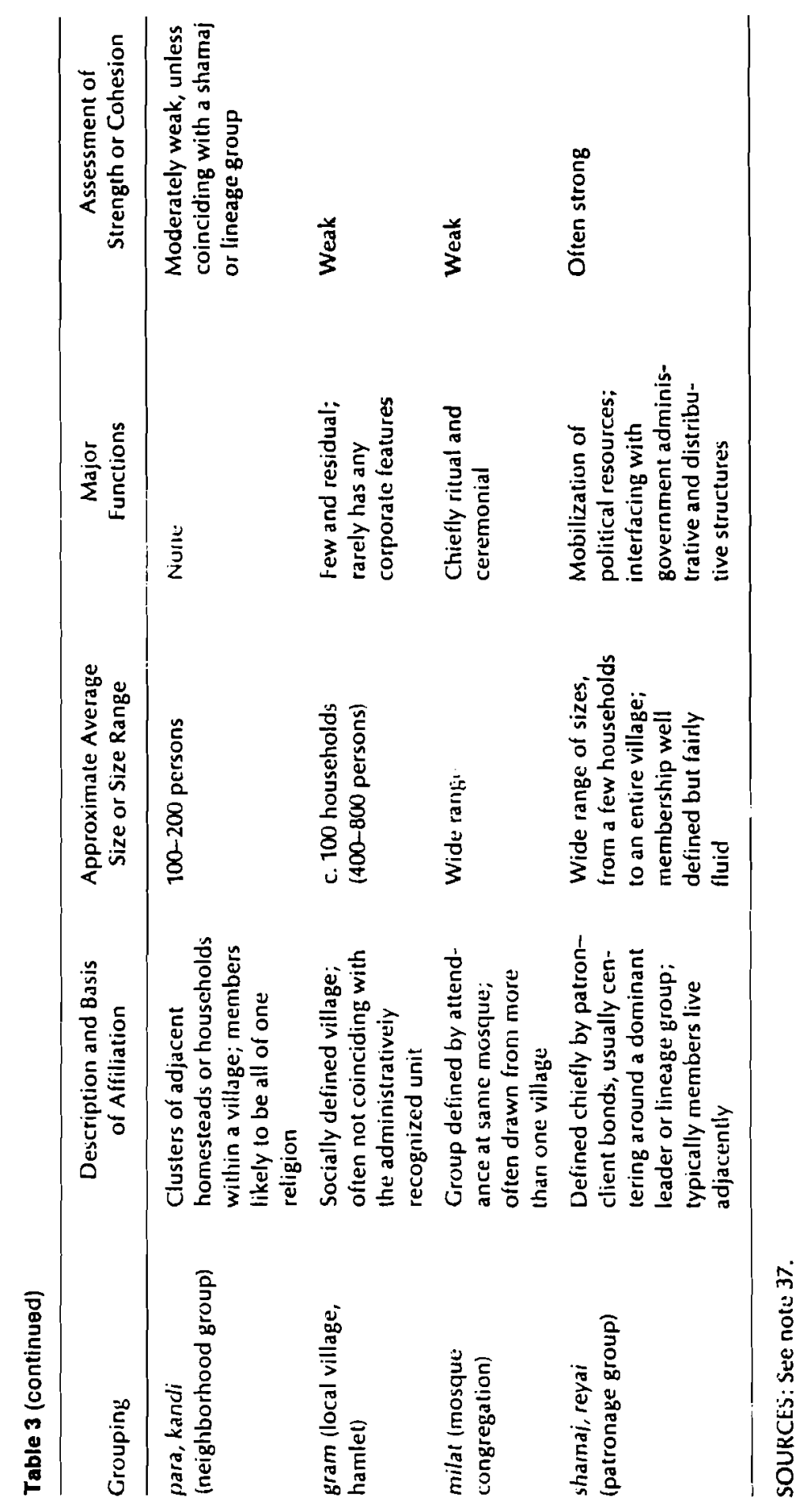


surplus farms rise. Former clients must be abandoned, left to attach themselves to the formal wage system. And growing commercialization, reflecting the new values and opportunities associated with technological change and increased urban contact, is beginning to transform an economy based on personal relations into one that is formalized and monetized. This process, which might be seen as a healthy sign of modernization in many countries, is a mixed blessing in Bangladesh. Farmers find outlets other than traditional power maintenance for their surplus: investment in nonagricultural enterprise or in education, new consumer goods, and so on. Increasingly, there are signs that large landowners are reluctant to let to their kin; sharecropping is giving way to pure tenancy; and, as noted earlier, patron-client bonds are being supplanted by an employer-employee relationship. Market forces that permit the wealthier peasants to shake free from their former obligations tend to erode what little security the landless and near landless now possess. More people in these latter classes are compelled to be geographically mobile, responding to seasonal labor demands and in turn depressing local wage rates. ${ }^{44}$ Although traditional patronage and kin ties probably still dominate rural relations in most of the country (systematic information on the pace and extent of change is lacking), the directions and impetus for movement toward a more formalized, impersonal economy are clearly evident. ${ }^{45}$

Our overall impression of rural social organization in Bangladesh, then, is one of diffuseness. Duties and obligations run in various directions, and functions are split among different kinds of social groupings. Local society is fragmented into groups organized around leading families, which are often at odds with one another. No strong territorial groupings exist to pull community interests into line. This traditional structure is changing slowly, increasingly coming to be based on formal commercial relations, but this process is still in its early stages. We turn now to the implications of this local system for rural development.

\section{The Politics of Local Change}

We have looked briefly at the patterns of economic and social organization in rural Bangladesh. How do these relations set the context of rural development-defining command over resources, limiting the scope of individual action, and promoting or hindering economic progress?

Agriculture in Bangladesh, as we have seen, has yet to show the dramatic improvements that the new technology can potentially offer. Yields are still low, and government attempts to foster change have met with mixed success. Certainly such problems are by no means unique, but in Bangladesh two special circumstances worsen matters: the general social diffuseness just described and the absence of the kind of local administrative system that could provide a firm institutional setting for development. 
Social diffuseness-the lack of community integration and purpose we noted earlier-would be less of a problem if peasant farming were carried out on an individual basis. But the new agricultural technology makes greater demands than before on organization and cooperation, both of which are weak in rural Bangladesh. Village society was seen as cut across by various social groupings, often in conflict. In the case of rival factions, competition can be outrightly violent. Bertocci (1970) has drawn a striking and disturbing parallel between the emergence and potency of factional groupings in Bangladesh society and the situation in Sicily that led to the growth of the Mafia. Vertical relations can also involve violence and intimidation: A recent series of village studies by Shapan Adnan presents a stark picture of this aspect of village life. ${ }^{* 6}$ This atmosphere of competition and conflict not only provides an insecure setting for individual initiative, but also ensures that the benefits of development go mostly to the powerful. Distribution of fertilizer and control of irrigation are often cornered by a dominant family or factional group, to the detriment of the rest of the community.

The problem here, of course, is not that Bangladesh villagers are inherently unable to cooperate-many efforts to form rural cooperatives have been quite successful-but rather that, without strong outside support, traditional social and economic segmentation eventually blocks collaborative effort. In some societies, territorial bonds supply a sufficient measure of community responsibility to avoid such an outcome, but in Bangladesh, as we have seen, territorial affliation is weak.

If traditional social arrangements impede agricultural development, the local administrative system imposed on them does little to help matters. In Bangladesh, as we noted earlier, the various colonial regimes did not leave behind a strong system of local government capable of responding to national goals and providing a firm institutional setting for rural change. And more recent attempts to fill this gap have merely strengthened the existing obstacles. The basic unit in the regional administrative hierarchy is the union, corresponding to about 15 census villages on average, with a population of 15,000 to $20,000.47$ Unions are governed by elected councils, which have broad authority for local welfare and power to levy land taxes. When these councils were instituted under universal adult franchise in 1959, most members, not surprisingly, came from the rural elite-the larger surplus farmers and the leaders of dominant lineages or patronage groups. ${ }^{48}$ Council membership and, in particular, the chairmanship were major new sources of local power and patronage. To the extent it had wished to do so, the national government in reaching downward through the administrative hierarchy failed to gain a purchase at the union level. Far from introducing a territorially based structure at odds with traditional village power relations, the administrative system at its lowest level became effectively an instrument of those relations.

As a result of this capture of the local system by the rural elite, their 
interests, not those of the average farmer or those proclaimed by the national government, continued to dominate the rural scene. Under the traditional social system these interests had little to do with agricultural innovation. For the rural well-off, lending money at high interest rates (often more than 100 percent), buying up mortgaged land, and building the strength of followers provided faster routes to position and status than painstaking investment in agriculture. ${ }^{40}$

If attempts to create an effective administrative structure independent of the local elite thus foundered, most government programs to directly promote rural development have met a similar fate. The best known case is the history of the cooperative schemes set up by the Bangladesh Academy for Rural Development (the Comilla cooperatives)..$^{\text {so }}$ In their own terms, these cooperatives had substantial early success in organizing small and middle peasants and in providing members with seed, fertilizer, credit, and so on. But over time, and especially with the attempted countrywide replication as the Integrated Rural Development Programme, most cooperatives came to be dominated by the rich farmers who could get themselves elected to the managing committees. (The process is of course familiar in cooperative movements in many countries.) These rich farmers were able to monopolize inputs, re-lend cheap government loans to others at higher rates, and control irrigation groups to the benefit of themselves and their supporters. The original intent of the scheme, to mobilize and assist the small farmer, was achieved only briefly. Programs that have sought to benefit the poorest rural classesthe Rural Public Works Programme and various other food-for-work schemes-seem to have been less open to direct capture. But if these efforts had been on a scale to make a significant impact on rural employment or distribution, we would expect that before long they also would have conformed to local political and administrative realities. ${ }^{31}$

In short, the segmented social order that characterizes rural Bangladesh, while it performs some useful functions, works to obstruct collective agricultural interests at the village level. Government attempts to impose outside organization and direction have for the most part been taken over by traditional forces, which have diverted them to their own ends.

As local society becomes more commercialized, these politics of rural development are likely to change. Rural power, traditionally derived from lineage rights and more recently from local government authority, is now shifting to an economic base. Increasingly, those who can capture a disproportionate share of the new technology and its supporting infrastructure become the new rural elite. Under capitalist agriculture the landlords, as Wood (1976, p. 149) puts it, "exchange the benefits of a respected leadership position for those based on the more naked reality of economic power." It is possible, of course, that this new economic basis of society will transform traditional patronage leaders into a class of well-behaved petty capitalists anxious to invest in rural growth. But if the new elite 
does begin to invest heavily in high-yielding technology, there is a danger that this could result in a speeding up of land transfer and a further concentration of resources, with negative consequences for the spread of benefits to the lower levels of society. Instead of being a powerful force in the modernizing of society, high-yielding agriculture could well become little more than the new instrument by which a rural elite maintains its traditional position. ${ }^{52}$

This picture of local society would not be complete without mention of the urban scene in Bangladesh. Cities presently have little weight in the overall economic and social structure, containing less than 10 percent of the population. Dacca (1974 population 1.7 million), Chittagong $(900,000)$, Khulna $(400,000)$, and Narayanganj $(270,000$, but essentially part of the Dacca metropolitan area) are the only major centers. ${ }^{53}$ But with this small base it takes only a slight rural-urban drift to induce rapid urban growth. These four cities nearly trebled in size between 1961 and 1974-an annual rate of increase of 8 percent, or more than three times the growth rate of the rural population. Yet even at such a growth rate urban areas are absorbing less than a fifth of the rural natural increase each year.

New arrivals in the cities come from the full range of rural society. For some migrants, mostly from the rural elite, the cities are openings to an urban middle class, offering education and the prospect of jobs in government or the private sector. For the less well-off, this small modern sector supports considerable lower-status employment, ranging from wage labor in manufacturing and construction to fringe activity in small-scale commerce and services. And in bad seasons, such as that of 1974, the cities also become the last refuge of the rural destitute.

The recency of significant urbanization in Bangladesh means that it is too early to assess the nature of the society that is evolving. Almost by definition urban behavior is less influenced by family and kinship ties, whether because of emerging middle-class attitudes or because of the imperatives of day-to-day subsistence. But new social groupings appear. The poor now tend to be residentially separated, often in squatter settlements (Dacca was estimated to have 400,000 squatters in $1972^{54}$ ), and awareness of their common interests leads to some community solidarity. Young people, particularly students, become a distinctive social group and sometimes, as in the events leading up to the 1971 war, a political force. And factory workers and even government employees are mobilized in labor unions. Administratively, a sometimes tenuous stability is maintained with help from a visible military and police presence.

To summarize this account of the local context of development, we see access to land and distribution of security as the important traditional organizing forces in the rural economy and society. But both are threatened as landlessness increases through rapid population growth. 
Agricultural change is impeded by a social system that allows development initiatives to be captured by the better-off, and social cohesion is fragile and exclusive, making it difficult to organize change that would benefit society as a whole. A growing commercialism may help "modernize" this traditional society, but at the same time it is weakening informal mechanisms of distribution through patronage, and may well lead to a further concentration of assets so that the larger masses are not reached by development. Finally, cities are growing rapidly, but are still small, providing at best a modest outlet for the rural poor.

\section{Demographic Processes in Rural Bangladesh}

We have described the local setting in which individual and family life in Bangladesh is played out and have seen some of the changes now taking place. A major factor in these changes, as we saw also at the aggregate level, is the rapid pace of population growth. This puts everincreasing pressure on a restricted and uncertain environment, makes the swift adoption of new productive technologies critical, and, with a limited land area, causes a downward spiral of land impoverishment whereby the security of one's place in the distributional system becomes all important. In this section we examine the demographic processes that drive Bangladesh's population growth, setting our analysis within the context of the family. We begin by looking at mortality: how the falling death rate bas altered the family life cycle, how mortality processes work at different levels of society, and the prospects for continued declines. In discussing fertility the relevant context is not only the family but also the distinctive place that women occupy within it in Bangladesh. After setting this context we then go on to examine the actual mechanisins of fertility in some detail: the biological constraints on numbers and timing of births and the particular social and economic incentives that maintain fertility at bigh levels.

\section{The Family}

under Changing Mortality

In the past three or four decades death rates have halved in Bangladesh. For the family this means several changes: More children survive, parents live longer, child dependency may have increased, more sons survive to inherit land, and so on. We look at some of these changes now.

Most people belong to either nuclear or patrilineal extended families, the latter usually organized as separate nuclear families grouped together residentially as a homestead. Families, of course, have a life cycle, so that 
at any time a substantial proportion of the population will be found living singly or in other types of households than the nuclear or patrilineal type. Table 4 indicates that in 1960 one-third of all households were "nonstandard" in this sense. Given Bangladesh's almost universal marriage, the situation largely reflects demise of families through death of a spouse, usually the husband.

Table 4

Distribution of Bangladesh Households

by Family Composition, 1960

\begin{tabular}{|c|c|c|c|}
\hline \multirow{2}{*}{$\begin{array}{l}\text { Composition } \\
\text { of Household }\end{array}$} & \multicolumn{3}{|c|}{ Distribution of Households (Percent) } \\
\hline & Urban Areas & Rural Areas & Total \\
\hline One person only & 11 & 4 & 5 \\
\hline Husband and wife only & 5 & 5 & 5 \\
\hline \multirow{5}{*}{$\begin{array}{l}\text { Husband and/or wife with own children } \\
\text { Husband and/or wife with or without } \\
\text { own children but with parents and/or } \\
\text { daughter-in-law } \\
\text { Households comprising other relatives } \\
\text { or nonrelatives }\end{array}$} & 29 & 33 & 33 \\
\hline & & & \\
\hline & 22 & 31 & 30 \\
\hline & & & \\
\hline & 33 & 27 & 27 \\
\hline All households & 100 & 100 & 100 \\
\hline
\end{tabular}

SOURCE: 1960 Housing Census (Census of Pakistan 1967, vol. 9, Table 8).

The family life cycle starts with marriage. For the average woman in Bangladesh this takes place before age 15 . By age 20 only 5 percent of women are still single; less than 0.1 percent never marry. Men tend to marry in their $20 \mathrm{~s}$; the average age is 23 , but with a bigger spread in age than for women. There may have been a slight increase in marriage ages in recent decades, particularly in the last 10 to 15 years; later we consider the prospect for more substantial changes in the future. ${ }^{55}$ As we noted earlier there is some doubt about the exact level of fertility, but a total fertility rate of about seven children per woman may well prevail. ${ }^{56}$

What has been the impact of mortality decline on family size? A rough answer can be obtained by contrasting the process of family building under the present mortality regime with that of the 1930s, assuming (realistically) that fertility patterns have remained much the same. Suppose that in both cases a woman is married at age 15 to a man aged 23 and survives through her reproductive years. Figure 3 shows the resulting size and duration of the nuclear family in the two mortality regimes. The family is assumed to break up with the death of the husband, whose life expectancy at marriage would have been about 30 years in the 1930s, 40 years in the 1970s. (Figure 3 does not give any indication of variability 
Figure 3

Average Size and Duration (to Death of Husband)

of Nuclear Family in Bangladesh,

under Mortality Regimes of 1930s and 1970s

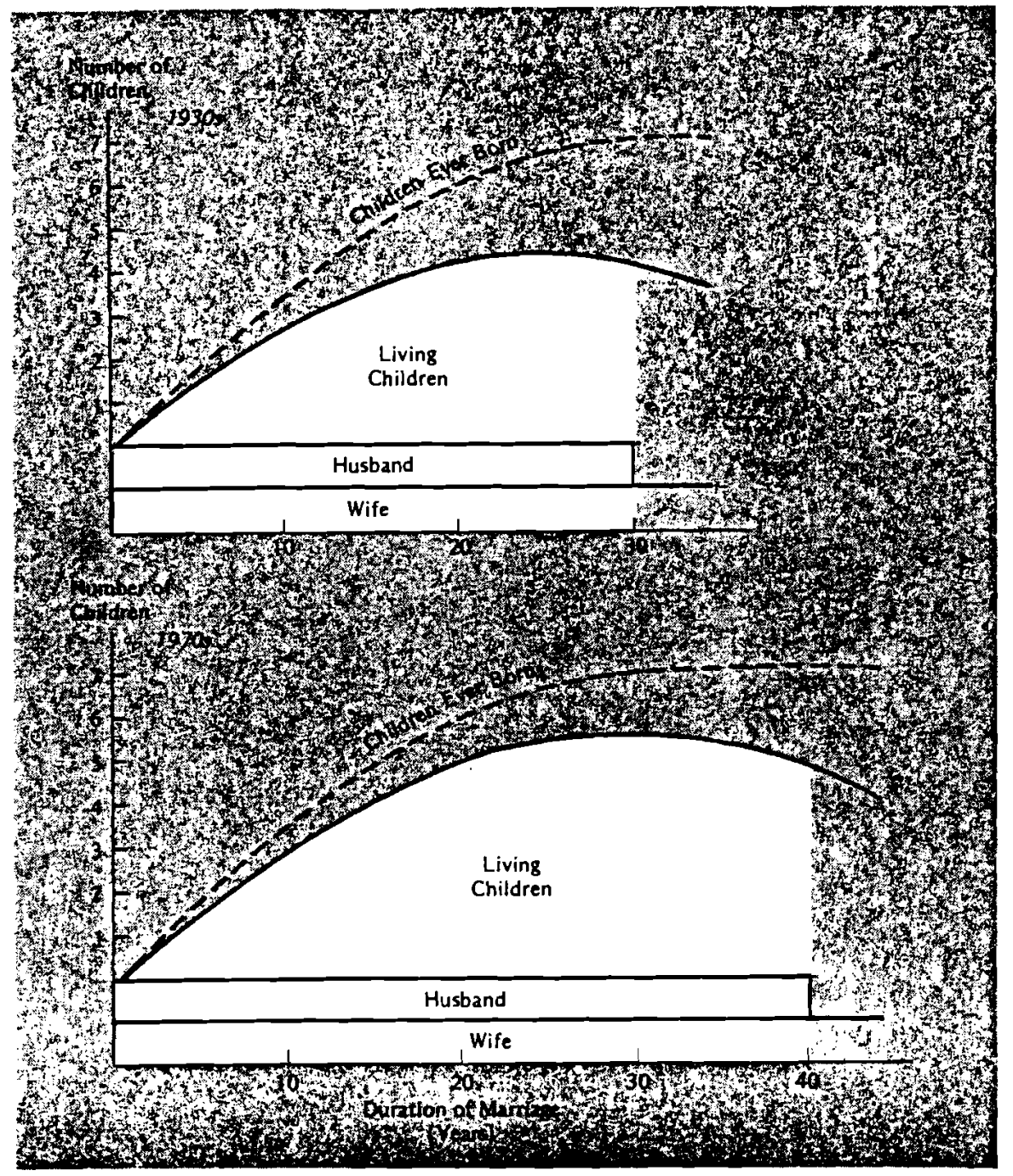

in mortality and fertility among families. For example, the poorest families may still experience the older pattern of mortality. Some of this variation we discuss below; here we deal with the average.)

The main aspects of the new demographic situation now begin to emerge. More children survive at all marriage durations: The new average family is bigger. In the 1930s only about half of all children born reached adulthood; in the present decade three-quarters do. (See Table 5 for 
approximate proportions of children surviving through childhood years.) The male patriarch, living ten years longer than previously, lengthens his period of domination over his family and causes a correspondingly longer wait for his children to inherit. Land must now be divided among an average of 2.4 surviving sons instead of 2.0 , assuming that daughters are bypassed. And with improving longevity for women as well as men, the expected period of widowhood remains lengthy (around ten years), a fact that becomes significant when we consider the dependent position of women.

Table 5

Approximate Age Pattern of Child Mortality, Bangladesh, 1930s, 1950s, and 1970s (Excluding Effects of Major Disasters)

\begin{tabular}{cccc}
\hline & \multicolumn{3}{c}{ Probability of Surviving to Each Age (Percent) } \\
\cline { 2 - 4 } Age in Years & 1930 s & 1950 s & 1970 s \\
\hline 1 & 72 & 80 & 85 \\
2 & 65 & 75 & 81 \\
5 & 58 & 70 & 78 \\
10 & 55 & 67 & 76 \\
15 & 52 & 65 & 75 \\
\hline
\end{tabular}

SOURCES: Estimates for the 1930 s and 1950 s assume life expectancies of 28 and 38 years respectively, distributed according to the Coale-Demeny West model pattern. Estimates for the 1970 s are taken from the life table derived from the 1974 Retrospective Survey.

The fact that more children survive than previously might seem to imply that the burden of child dependency within the family has risen substantially in recent years. Yet this is not necessarily so. Child dependency in Bangladesh is difficult to define. Children are usually put to useful work between the ages of six and ten, and by their early teens they have ceased to be economically dependent. ${ }^{57}$ Moreover, in the early years of marriage, when the dependency burden is greatest, the nuclear family is quite likely to be part of a larger patrilineal family group. Most of all, though, marriages (survival of both partners) in this new situation last about ten years longer. Thus, although more children survive to burden each family, the family has a longer productive life in which to reap the benefits of these children. The higher dependency within the population is scarcely noticeable within each family.

We can conclude that once the family is set up it does not experience the results of the mortality decline very directly in its life cycle. Where, then, are these demographic pressures felt? At one point in the life cycle the economics of continued growth are experienced directly-in setting up a household, when land must be subdivided or new means of sustenance 
found. Even here, though, the way is likely to be smoothed by the patrilineal family. Many of these families, as we have seen, act to some degree as corporate units-sons can farm patrilineal land, with the father holding title until his death. To a lesser extent demographic pressures are also felt when the family tries to enter a child into the stretched labor market. Once a share of economic resources is procured, however, the family can settle down to a life that would appear to be less steadily eroding than the aggregate figures would show.

Mortality:

Processes and Prospects

While family life has lengthened, reflecting current lower mortality, quality of health in Bangladesh remains poor. Per capita protein and calorie consumption, already at very low levels in the early 1960s, are estimated to have declined over 1960-75. The deterioration was probably more pronounced for the landless rural population and the urban poor, both of whom experienced a substantial drop in real wages in this period. ${ }^{58}$ Chen and Chaudhury (1975) think it likely that average body weight declined in the 1960s. Malnutrition impedes both physical and mental development of the young and, through its weakening of the body's defense systems, is a basic contributor to mortality and morbidity in the population as a whole.

In the conventional cause-of-death categories, the largest contribution to present overall mortality is from diarrheal diseases (including some cholera), which may now account for as much as a third of all deaths. Other significant contributors are tuberculosis and other respiratory diseases, tetanus (an important cause of neonatal mortality), and the usual chronic diseases of old age, which have become more salient as epidemic diseases are reduced.58

There is little direct evidence on the prevalence of illness in the population, but it is undoubtedly high. Public knowledge of disease transmission is primitive and health services are sparse. ${ }^{80}$ For even moderate death rates from infectious and parasitic diseases to persist, a large proportion of the population must suffer from these diseases and experience the enervation and low morale that go with them.

Likely future trends in mortality are difficult to assess. Mortality risks, far from being equally distributed through the population, closely reflect access to the local economy. To simplify matters somewhat, two mortality processes can be seen at work, one for those above subsistence, the other for those thrown upon the margins. For those above subsistence, much will depend on further progress in public health. Relatively easy treatment for diarrheal diseases now exists through the prevention of dehydration (oral rehydration therapy), which has yet to be widely exploited. Greater availability of antibiotics and advances in general 
health education would also have potentially important effects on mortality. All of these, however, call for substantial improvements in the level of health services. For the above-subsistence death rate to continue to fall, development of an effective health infrastructure is probably more important than dramatic improvements in the economy.

Those compelled to subsist at the margins-whether geographic or economic-face much higher mortality risks. On the margins of settlement -for example the char lands in the delta mouth-recurrent flooding and tidal bores cause high disaster fatalities (see Table 1). For those forced onto the economic margins-a numerically more important group-a less dramatic process occurs. These families become gradually cut off from the distributional system, and in hard years are the first to die. Figures are scant. Data from an intensive study of one small rural locality indicate child mortality rates for the poor nearly double those of the well-off, and an even greater class differential in the frequency of widowhood in middle life. ${ }^{61}$ Another village study, giving figures from a famine year, shows death rates in landless families three to four times those of families with more than 1.2 hectares (see Table 6).

Table 6

Death Rates by Family Landholding

in a Famine Year, Companiganj Thana,

Noakhali District, 1975

\begin{tabular}{lcc}
\hline $\begin{array}{l}\text { Size of Landholding } \\
\text { (Hectares) }\end{array}$ & $\begin{array}{c}\text { Crude Death Rate } \\
\text { (Per 1,000) }\end{array}$ & $\begin{array}{c}\text { Death Rate of } \\
\text { Children Aged } \\
1-4 \\
(\text { Per 1,000) }\end{array}$ \\
\hline 0 & 35.8 & 86.5 \\
Less than 0.2 & 28.4 & 48.2 \\
$0.2-1.2$ & 21.5 & 49.1 \\
More than 1.2 & 12.2 & 17.5 \\
\hline
\end{tabular}

SOURCE: MCCord (1976).

Overall, therefore, we see a bifurcated mortality process in Bangladesh: lower risks for those who are well-off, much higher risks for those on the margins. With growing impoverishment, this second type of mortality could become more dominant. Rough calculations show that the process of increasing marginality through landlessness could add two to three points to the average crude death rate in the next decade. But preoccupation with average rates makes little sense when mortality varies so widely by class: Improvements in the national average would be small comfort to the many who risk being pushed downward in the economic scale to face a distinctly harsher regime of mortality. 
Women and the Family

Before discussing fertility it is worth pausing to look at the place of women in Bangladesh. This subject scarcely arose in our earlier survey of economic and social organization, for in Bangladesh as in few other countries women's work and social life lie within the household and their status is conferred by husband or son. Very few women work in the fields or in other jobs away from the house. For the most part, activities in rural areas are clearly divided between the sexes. Men undertake the outside stages of grain production-sowing, crop husbandry, and harvesting; women take on the stages that can conveniently be performed within the household compound-husking, parboiling, and preparing next year's crop. Women also fulfill the usual rural household duties: care of children, preparation of meals, and possibly care of a few domestic animals. ${ }^{62}$

We have already argued that the main problem for the individual man in a marginal environment is to tie himself into the distributional system-to purchase security through any available economic or social means. Women are more constrained in their search for security. Individual initiative is largely ruled out. Strong traditions of purdah dictate that respectable women do not engage in trade or feldwork or leave the family for other than traditionally specified visits to relatives. Separation and divorce are real threats, especially if the woman proves to be childless. ${ }^{63}$ And early loss of the husband's ability to provide, through illness or death, can become a disaster for a family in its middle years. ${ }^{64}$ These threats of loss, together with social restrictions on acting for themselves, put women in a position of high risk that rises as life progresses. Women respond by strengthening what familial bonds of security they can. The part inheritance allowed to daughters under Islamic law (half that to which a son is entitled) is usually unclaimed, but bartered to a brother in exchange for a promise of later security should they be widowed or divorced. ${ }^{65}$ Fulfillment of duties to one's husband and larger family takes on a special importance, as does production of sons as a guarantee for later years. Thus, women strengthen whatever lateral and vertical family ties they can, but in doing so they find themselves carrying out roles dictated by the interests of husband, sons, or husband's family.

If husband and wife have separate but unspoken strategies to protect their interests and security, so, too, does the family as a whole. The degree of purdah observed is part of family strategy. Purdah provides respectability and status. It enhances marriage prospects for daughters and helps maintain the family position and name-a valuable asset that yields power and influence in dealings with the community. Thus, although its demands are costly and restrictive, when families become better off they tend to keep stricter purdah. ${ }^{\circ 8}$

Marriage of sons and daughters is a highly planned part of family 
strategy; as in most of the subcontinent, it is an arrangement between families. Early marriage enables larger family interests to dominate those of the young couple in the first 'few years. And where high fertility is valued, it allows the family as a whole time to accumulate children despite the long lactation periods that prevail in Bangladesh-a strategy that goes far toward maximizing the chance that children will not only be born but also will survive past the high-mortality years of infancy.

Different treatment of sons and daughters also reflects family interests at work. Daughters do useful household work, but unlike sons are not in a position to bring in outside wages or provide later support. Under such circumstances, it falls within family interests to pass on daughters at an early age but to hold sons as long as possible-a factor that may contribute to the large sex difference in age at marriage.

In each of these cases, behavior rational to the family helps perpetuate a position of low autonomy for women.

Fertility:

Constraints and Supports

The high level of fertility in Bangladesh occurs fairly uniformly across regions and classes. Larger landowners have slightly higher fertility than average; poorer women and urban women tend to have fewer children, but all the differences are small. Lower average fertility does seem to prevail among the urban middle class, but this group is of insignificant size and is unlikely to absorb large numbers in the next two decades. ${ }^{67}$ Although average fertility varies little across groups, within any group of women variation can be large, reflecting mainly the biology of the process. For currently married women in their 40 s in 1974 , the distribution by children ever born is shown in Figure 4 . About 50 percent of the women bad borne six or more children, while 30 percent had borne four or fewer. Relatively small numbers of births in a completed family are by no means rare.

In the absence of any obvious reasons that birth rates should be changing, it has been conventional to assume a roughly constant level of fertility over past decades (see Figure 2). There are, however, year-toyear fluctuations-for example, a substantial drop in the year following the 1971 war and again after the 1974 famine. ${ }^{88}$

It is clearly important to try to explain why fertility is at its current level. Later in this section we argue that social and economic pressures on families combine to push fertility upward to a natural limit. Yet, with a female reproductive life of 35 years or more and with early and universal marriage, why should that limit be a total fertility rate as low as seven? Rates between eight and ten have been reliably recorded in populations with later age at marriage than in Bangladesh. (Figure 5 compares 
the age pattern of fertility in Bangladesh with one such population, the Hutterites of North America.) The answer is best given by listing the main factors, mostly biological and partly due to societal arrangements, that constrain Bangladesh's fertility below these extreme levels.

Figure 4

Distribution of Women Aged 40-49

by Number of Children Ever Bom,

Bangladesh, 1974

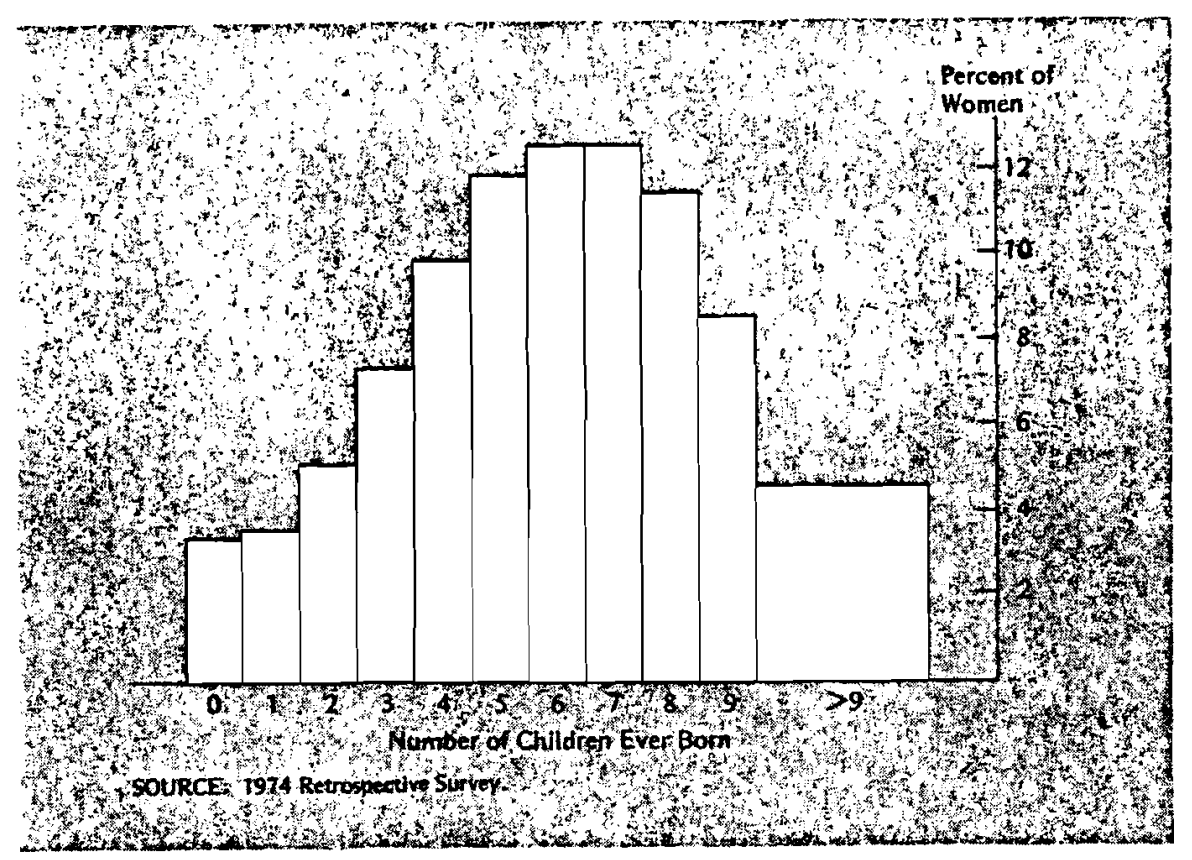

First among factors depressing natural fertility is the fact that women in Bangladesh experience periods of lactational amenorrhea (i.e., suppression of ovulation as a consequence of breastfeeding) that are among the longest ever recorded. Extended breastfeeding is the main reason Bangladesh is not reproducing like the Hutterites. Lactational amenorrhea accounts for nearly 19 months of the average 34-month interval between births. Since it is not difficult to visualize forces that would tend to shorten breastfeeding, there is a constant threat hanging over prospects for fertility reduction. If the lactational period were reduced so that amenorrhea lasted only 11 months, the level prevailing in Punjab, total fertility would be 25 percent higher. ${ }^{60}$ (Of course, mortality would also increase with shortened lactation because of the removal of the protection that breastfeeding and birth spacing afford to infants. The net 
Figure 5

Age-Specific Fertility Rates in Bangladesh, 1974,

Compared with an Extreme "Natural" Fertility Schedule

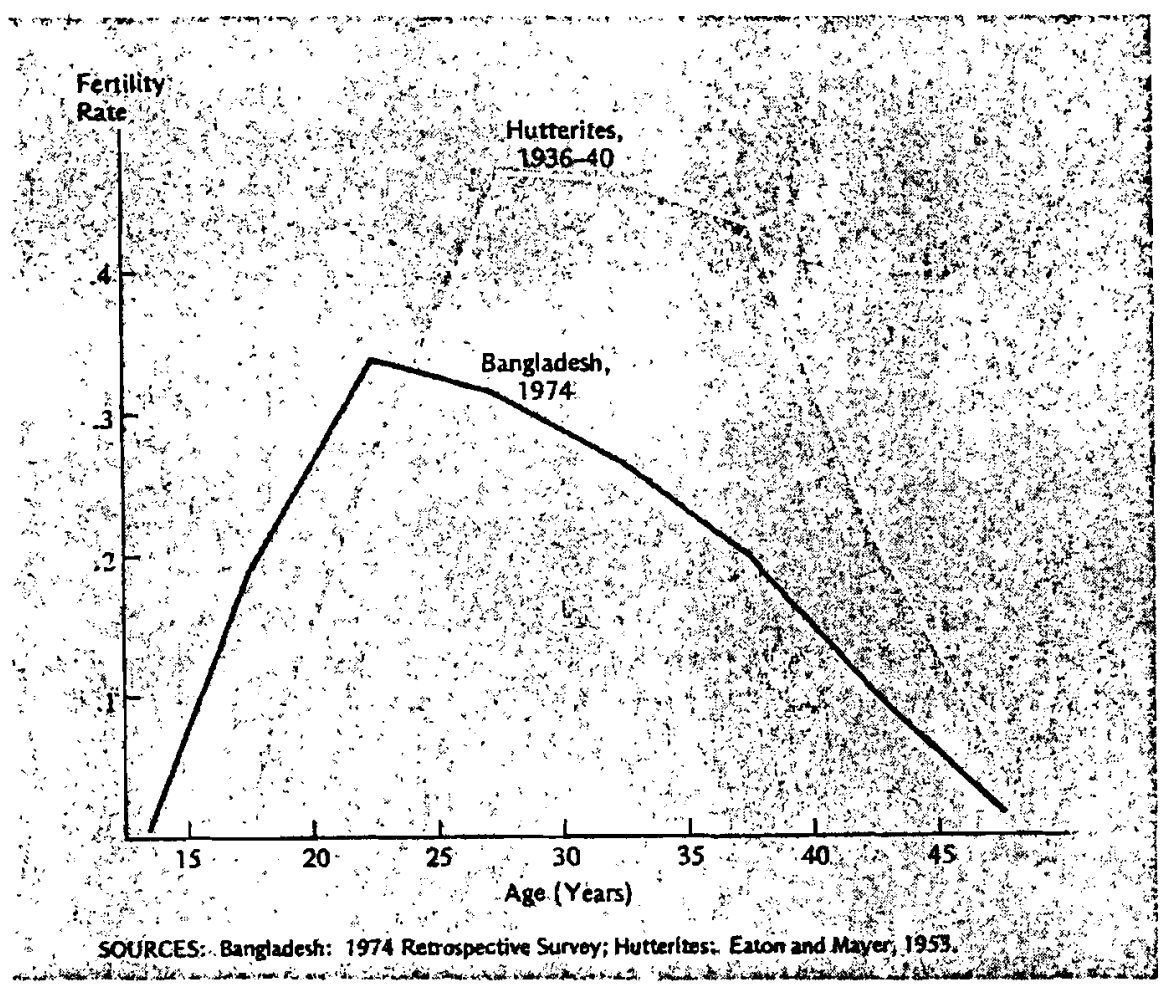

increase in surviving children could be quite small..$^{0}$ ) Nutritional inadequacies suffered by poorer women add slightly to the length of amenorrhea. ${ }^{71}$

Less important as a depressant to fertility, but still significant, is absence of the husband through death, divorce, or occupational migration. We have already mentioned the high frequency of widowhood toward the end of the reproductive years. Husbands are considerably older than wives, so that remarriage prospects for women are few (and are further reduced by social disapproval). A rough calculation using 1961 marital status data suggests that fertility could be 6 percent higher if all husbands survived until their wives reached the end of their reproductive years. ${ }^{72}$ For divorce, a similar calculation gives a fertility effect of 5 percent. Physical separation of couples as a result of seasonal or other kinds of occupational migration is difficult to measure, but not negligible. One study estimates that it lowers fertility by 10 percent. ${ }^{73}$ Differential mortality and migration probably account for most of the class difference in fertility.

As a factor in reducing fertility, primary sterility appears to be rela- 
tively unimportant in Bangladesh. The 1961 census found only 5 percent childlessness among married women over age 45; the 1974 Retrospective Survey found 4 percent. ${ }^{74}$ Of course, female sterility would often be a reason for divorce; so this category overlaps the previous one. It is not clear just how much secondary sterility exists, but with the high morbidity levels it may be substantial. ${ }^{75}$ This is probably the main reason for the quite large numbers of women with low completed fertility in Figure 4.

Finally, contraception is not at present a major factor depressing fertility in Bangladesh. The 1968-69 National Impact Survey recorded only 3.7 percent current users of contraception among married women of reproductive age. ${ }^{76}$ If used effectively, contraception of this amount would mean a birth rate of at most 3 to 4 percent below its level in the total absence of use. There is no reason to suppose more than a slight increase in the user rate over the last decade. The problem is partly a lack of knowledge of modern contraception and very limited access to regular supplies and services. The extent of demand for contraception is a controversial issue still to be fully resolved, but little evidence points to a latent demand of large proportions. ${ }^{77}$ An important experiment undertaken in Matlab thana in Comilla seeks to probe the limits of contraceptive demand by a saturation distribution scheme. Results indicate a ceiling of around 17 to 18 percent of married women in reproductive ages using the proffered supplies (a peak attained after three months), tailing off after two years to less than 10 percent despite continued intensive effort put into the supply system. ${ }^{78}$ Abstinence, a sure contraceptive method available to all, does not seem to be much used as an intentional measure for controliing births. For example, the taboo against sexual relations during breastfeeding, observed in many other cultures, is not strong in Bangladesh, nor is terminal abstinence after becoming a grandparent. (Breastfeeding itself does not seem to be used consciously for its contraceptive value, although evidence on this point is weak. It is possible that the usual practice of a wife's going to live with her mother for birth and subsequent recuperation is sometimes extended as a means of birth spacing.)

While satisfactory as an explanation of how completed total fertility comes to be seven and not nine or ten, we have not yet asked why fertility rates should be pushing against biological limits despite rapidly worsening man-land ratios and increasing impoverishment-trends that are well recognized by the people themselves. ${ }^{7 \theta} \mathrm{We}$ would not of course expect to see rapid adjustment to the new mortality conditions, but a generation should be a long enough time period to detect substantial signs of change. Yet fertility continues to remain high throughout the rural sector.

It is hard to believe that high fertility in Bangladesh is merely the result of blindness to choice. Certainly when we look at some of the individual efforts to improve economic position by adopting whatever 
means can be found, we see that peasants in Bangladesh as much as elsewhere seem quick to sense opportunities for even marginal progress. Perhaps it could be argued that the lack of access to modern contraception maintains fertility at high levels. But we have also seen that it is hard to give weight to this factor. Primitive means of contraception have always been available, and modern contraceptives offered on a saturation basis have generated at best a lukewarm response.

It is at the level of economic and social pressures that fertility supports are most likely to be found. It is difficult, however, to unravel the complex network of incentives. Starting at the family level, it is likely that in a situation close to subsistence, extra hands, especially male ones that can bring in a useful wage before age ten, could make a substantial difference to the family's well-being. Children are profitable as an investment. Evidence from the recent village study by Mead Cain (1977) supports this view: By age 12 the average male child has become a net producer; by age 15 he has compensated for his cumulative consumption; and by age 22 he has repaid the investment in himself and one sister. Parents therefore realize a net return on children, a return that would be lower if rural wages fell further, but one that would be higher if sisters' household work were valued and if later family support were included. This is not to say that parents perform any conscious calculations on fertility, but an awareness of the advantage of children as extra income can well be present in high degree.

The finding that children are profitable after 15 or so years in a society that lives close to the margin may not be sufficient to show that high fertility makes sense. The early years of childhood are a consumption drain, and under circumstances where day-to-day survival dominates any future payoff, why should parents carry the extra burdens of child consumption? It is here that we refer back to our discussion of the family. For the early years of marriage, we found that the patrilineal family lightens much of the burden of childbearing; later we saw that at no particular point in the life cycle do incentives against childbearing build up. And women, in their special position of dependence, find sons the highest form of security against privations of widowhood. Cain makes a further interesting point here. In rural Bangladesh, if a husband is incapacitated or dies before his eldest son is old enough to assume control of family property, the family faces a period of extreme vulnerability when assets are easily lost through lack of male labor or through social predation. ${ }^{80}$ Future security therefore makes it important for women not only to have sons, but also to have them as early as possible in the marital life cycle.

Economic interests in producing children vary somewhat by class. For the relatively affluent landowner, better survival prospects of children are probably not sufficient incentive to cut back fertility. Children 
can be educated, sent to cities, and used to expand his local power. Subdivision of land among children poses little threat: Family holdings can be augmented through marriage and by purchase or foreclosure of mortgages, and other occupational outlets are increasingly available.

For those lower down, children provide, besides direct labor, the only real security against loss of holdings and penury in later years. Thus, whether parents are concerned mostly for their own welfare or for that of their children as well, high fertility is an advantage. That the children themselves are then likely to inherit plots too small to support a family, a factor assumed to favor low fertility among the peasant proprietors of preindustrial Europe, is necessarily here a secondary concern. The extreme uncertainties of the local social and economic setting do nothing to encourage growth of peasant proprietorship in Bangladesh.

At the bottom of society, lack of security overrides all other concerns. To the extent that attachment to a patron is possible, children can add "pleading power" as claimants in the labor market. ${ }^{81}$ And at this level childhood (and maternal) mortality runs highest. Families count themselves lucky if they can produce enough births so that even one son survives to adulthood. ${ }^{\mathbf{B 2}}$

It could well be argued that high-fertility behavior, though sensible for parents, runs counter to the interests of the local society and, therefore, that powerful social pressures might arise to oppose it. But for this to happen the local socioeconomic structure must be able to transmit and signal to parents the interests of the community at large. The pattern of social organization in Bangladesh that we outlined earlier appears singularly ill suited to such a task. Lines of social influence run through kin and patronage groups, whose membership and territorial boundaries are fluid and whose chief concerns are in serving the economic and political interests of the dominant families within them. High fertility poses little threat to those interests. At a lower level the patriarchal family can enforce early marriage and support high fertility of the nuclear unit by sharing the dependency burden of children and by awarding status with achievement of motherhood.83

We have sketched a picture in which the separate interests of extended families, of most nuclear families, and of factional groups press fertility to levels detrimental to the community at large. If each of these groups gains separately from its own actions, who then bears the costs? Three categories of people do. The community as defined by geographical location suffers through constant lowering of wages and use of scarce resources. Younger wives who are induced to deliver births at a rate beyond their wishes and sometimes their capacity also suffer. But most of all it is the next generation that loses-the people who in 15 to 20 years will somehow have to find new means of subsistence, move to marginal land, or attach themselves to the factional system. Fertility in 
Bangladesh has not fallen, because these are precisely the three groups that have traditionally had no way to organize to protect their interests: Unborn children by definition have no voice; women as yet have little standing outside the family; and villages or other territorially bounded social units in Bangladesh have a minimal role in the society.

\section{Prospects}

In describing the context of rural development and demographic behavior, we have been led to questions of economic class, social organization, family structure, and local government. We have seen how the individual aim of achieving security and a share of the social product in a tightening environment can act against collective demographic and development interests. And we have noted the special historical circumstances of the region that have left behind a power structure in which national ability to influence events quickly fades with administrative distance from Dacca.

What does the future hold for Bangladesh, and what questions of development strategy does the country face? We cannot expect to arrive at a narrow range of likely outcomes, both because of the innate uncertainties of the future and because much depends on the scope and direction of government action. But we can lay out the bounds of future development, separating the plausible from the highly unlikely. This done, we can trace some of the changes that will affect the course of development within these bounds.

\section{The Broad Picture}

Growth of population numbers must be expected to show the usual demographic inertia. If fertility and mortality change little from their present levels, the country would contain around 160 million people by the year 2000; if there were dramatic declines in both (as set out in the top panel of Table 7), the country would still have around 130 million people. Catastrophes of the magnitude recently experienced, as Baldwin (1977) has shown, leave the course of population growth little altered.84 One way or another, Bangladesh will probably have to support a population between 60 and 80 percent larger than its present size by the turn of the century and one that may then (as now) still be increasing by more than 2 million a year.

The main hopes for supporting these greater numbers lie with rapid agricultural development through improved water control, high-yielding crop varieties, and other components of the Green Revolution technology. Earlier we noted the apparent technological feasibility of a three- or even 
Table 7

Population Projections,

Bangladesh, 1978-2000

\begin{tabular}{lcrr}
\hline Projection & 1978 & 1988 & 2000 \\
\hline Rapidly declining mortality and fertility & 45 & 31 & \\
Birth rate (per 1,000) & 17 & 12 & 20 \\
Death rate (per 1,000) & 85 & 109 & 8 \\
$\begin{array}{l}\text { Population (millions) } \\
\text { World Bank "probable" projection a }\end{array}$ & 46 & 36 & 128 \\
Birth rate (per 1,000) & 18 & 14 & 30 \\
Death rate (per 1,000) & 85 & 113 & 10 \\
Population (millions) & & & 148 \\
Continuing high mortality and iertility & 47 & 43 & 40 \\
Birth rate (per 1,000) & 19 & 18 & 17 \\
Death rate (per 1,000) & 85 & 116 & 159 \\
Population (millions) & & & \\
\hline
\end{tabular}

a Bangladesh, Population and Nutrition Projects Department (1975, Annex 14-16); adjusted for consistency with revised 1974 census total, and with 1974 Retrospective Survey mortality estimates.

fourfold increase in rice production within a few decades; however, our subsequent account of the rural setting should serve to temper excessive optimism. It is highly likely that food production will lag far behind such possibilities, although it should not prove too difficult to achieve increases that more than keep abreast of population growth. But for families in agriculture the outlook depends as much on distribution as on total output. Those with substantial land will profit most from the new technology, both by direct productivity gains and, barring shifts in the present pattern of local administration, by their influence over local irrigation and distribution of needed inputs. Among marginal landholders the process of land impoverishment will continue, worsening present inequalities. And for the landless, the greater labor intensity of the high-yielding crop varieties is unlikely to do much to shore up rural wage levels faltering under pressure of a rapidly expanding work force. Nonagricultural employment on a scale able to absorb substantial numbers of those pushed off the land is difficult to visualize, but the pace at which such employment can be created will largely determine the welfare prospects for the bottom half of the rural population.

On the industrial side we saw a number of opportunities for sustained if modest growth, diversifying from the present jute manufacturing base. Natural gas will afford a large measure of energy self-sufficiency, at least for the next few decades, and already serves as feedstock for a growing fertilizer industry; however, other natural resources are lacking. Foreign exchange shortages may be eased somewhat by new revenues from 
natural gas exports and by a lessening need for food imports. (Direct foreign assistance net of debt service will probably not again reach the levels of the early years of independence.) Whetlier Bangladesh can emulate the few developing countries that have mcved successfully into manufactured exports is doubtful. Uncertainties here, besides domestic conditions, include future economic and political relations with Indiawith its enormous market and strong industrial base-and the scope of trade concessions in any new economic order beiween rich and poor nations. The most optimistic projection of growth in Bangladesh's industrial economy is probably that of Faaland and Parkinson (1976, p. 174), who think that an annual growth rate of 10 percent should be attainable under favorable conditions-a rate that would in 25 years create a sector comparable in size to agriculture. A more plausible projected rate of increase might be that of Indian industry over recent decades, an average of about 6 percent per year. ${ }^{85}$ As yet there is little sign of rapid growth getting under way: Present industry, operating in a climate of regulatory uncertainty, price changes, and intermittent shortages of foreign exchange and spare parts, has barely recovered from the 1971 war. ${ }^{86}$ Moreover, as important as aggregate growth in looking to Bangladesh's industrial development are choices concerning scale of enterprise, capital intensity, public or private ownership, and decentralization. Continuing political uncertainties leave these choices open.

What of the urban future of Bangladesh? If cities continue to increase at their recent rate, by the year 2000 about 30 percent of the population would live in urban areas. Even at this comparatively modest level of urbanization, cities would have to absorb another 35 million people. Put another way, the economy would have to support another 15 to 20 cities the present size of Dacca-or, more likely, a few vast urban agglomerations surrounding Dacca-Narayanganj, Chittagong, and perhaps Khulna. Under realistic assumptions on economic trends, this rate of urbanization is likely to be an upper limit. But even with slower economic expansion, cities may still grow at close to this pace; for whatever the increase in their industrial, commercial, and governmental labor force, they will inevitably also remain a dumping ground for the extruded rural poor. Urban growth depends on more than the speed and nature of industrialization.

In sum, allowing for a certain measure of speculation, the present situation can continue. In all probability, by the year 2000 the country will remain heavily rural; population will be larger by about two-thirds; agricultural output per head may have gained modest ground; and a high proportion of the rural population, probably more than half, will be landless. Per capita income will be higher, markedly so at the top of the distribution. For the majority of families, life will go on much as before, perceptibly better if things go well, harsher if they do not. 
We have put rough bounds on the paths of several development variables: population, agricultural output, industry, and urbanization. More important than the actual levels attained at the end of the century, however, are the quality and direction of the development process at that time and the values and organization of society that support this process. These deeper aspects of the economic and demographic system will determine whether the outlook in the twenty-first century will be one of promise or of disaster. In the years just ahead, much depends on the kind of social change taking place in the countryside, on the possibilities of rapid fertility decline, on the effectiveness of government intervention in development, and on whether the local economic system can be organized for sustained growth. To these questions we now turn.

\section{Social Change}

We have already pointed to the emergence of a more pronounced class structure in rural Bangladesh as subsistence peasants are shaken out of their place in the economy and added to the landless or near landless. The new agricultural technology will in all likelihood hasten this process, both by directly increasing inequality and by giving further impetus to the commercialization of farming-sharpening the once hazy line between landowner and wage laborer.

It is difficult to predict the outcome of increasing class prominence. Certainly it will do much to weaken the social stability resulting from kin and patronage ties. But factionalism is unlikely to disappear. Even in a commercial economy, control over employment and much else will remain in the hands of a few-a basis for continued recruitment of dependents. Rural class conflict will probably be mirrored in a strengthening of antagonisms between national political groups, and the possibility that this conflict will lead to a radical reorganization of the entire society cannot be ruled out.

New avenues of social mobility are beginning to appear. While the most deprived elements of the rural population have little chance of improving their lot, even if they move to the towns, for others there are increasing opportunities for upward mobility that bypass the traditional status hierarchy of rural society. Education is one route; attachment to the lower fringes of the administrative system is another. The new role of "brokering" between government programs and the local population is particularly powerful, although for the most part such opportunities have so far fallen to the traditional village elite. ${ }^{87}$

These contacts with the more modern parts of the economy serve to channel into the countryside new attitudes toward such things as the role of women, the value of education, age at marriage, and contraception. Government extension workers concerned with particular programs (irrigation, family planning, and so on) are another conduit into village 
life; and there is a small but increasing amount of travel between village and town. ${ }^{88}$ But the tangible realities of life may limit the degree to which new ideas can take hold. For the considerable fraction of the population at bare subsistence level, the notion of modernity scarcely applies. For them, a modernizing society may well be one in which their former place in the scheme of things no longer exists.

Deepening class divisions, as well as the slow appearance of modern attitudes, work to change the position of women. Women who are pushed downward in society through loss of husband or land join those who cannot afford the costs and restrictions of purdah and become free to take on new roles. Women's cooperatives, for example, have found their recruits typically to be drawn not from the elite but from the widowed, the landless, and the destitute. ${ }^{88}$ But there appears little prospect under present arrangements that change in women's roles will "trickle up" from the bottom of society. Gradual diffusion of new attitudes from the small, educated elite is the more likely source of change.

Under this pattern of change, and assuming no abrupt moves in social organization, it is difficult to see where strong incentives to restrict fertility will come from. For most families, children would continue for some time to provide income and security in a shaky environment. Large improvements in access to family planning services would of course help: Mopping up the residue of existing or easily drummed-up demand for birth control in Bangladesh might lower fertility by about 15 percent-to a birth rate of around 40 per thousand. Increases in age at marriage could also have a significant impact in reducing fertility. The changes we have described pose little immediate disincentive to early marriage, although their effects may mount up. To offset such factors, however, is the possibility of shortening periods of lactation.

Fertility declines are not of value irrespective of how they are achieved. A fall in the birth rate, for example, would be one likely consequence of a further deterioration of rural conditions-a product of worsening health status, physical separation of couples caused by labor migration, and general disintegration of stable family life. Children could even cease to be a paying proposition under such circumstances, adding voluntary pressure to this involuntary decline. ${ }^{.00}$

To summarize, we would not look for a major decline in fertility in Bangladesh in the next 10 to 15 years. A more likely pattern would be somewhat lower fertility for that part of the population whose circumstances are worsening, together with a slow chipping away of the fertility rate of the rest as contraceptive delivery spreads, women define new roles for themselves, and mortality, especially infant mortality, improves. This not very hopeful outlook supposes continuation of the present social and economic arrangements in rural areas. Under different circumstances demographic prospects could be radically altered. 


\section{Government Action}

We have explored the likely consequences of technological and social change; what of development through direct government action? The characteristic approach to development policy of the Bangladesh government, as of most others, could be described as programmatic. Successive governments over the past 30 years have set up a variety of programs designed to promote rural development and restrain fertility. The Integrated Rural Development Programme, growing out of the Comilla cooperatives, and the Rural Public Works Programme were mentioned earlier. Others include the Village Agricultural and Industrial Development Programme, the Thana Irrigation Programme, and a wide array of pilot programs concerned with agricultural extension, literacy, health, and so on. In family planning, a large-scale operation has been mounted, initially involving clinic-based services and later female paramedics based in the villages. ${ }^{\circ 1}$

The record of these programs is at best described as mixed. Many have shown encouraging results on a small scale, when close monitoring and supervision were feasible. But as the programs have been extended geographically and to encompass more activities ("integrated"), the results have become less impressive. For the most part, as we have seen, the programs have come up against local realities-a rural social system that works after a fashion, possesses a measure of stability, and is able to adapt to its own purposes the best intentions of planners.

There are also instances of privately sponsored rural development efforts in small regions that have been reported to be very successful. These include producer cooperatives, health clinics, women's organizations, and even village-level efforts to limit population growth. ${ }^{22}$ While of considerable interest in themselves and for their potential to shed light on feasible mechanisms by which communities can be organized, these efforts have yet to demonstrate any value as pilot projects for countrywide programs. The effectiveness of the Swanirvar (village self-reliance) movement, recently initiated by the government, may provide an interesting test of this question. As this movement solidifies into a program, there seem few reasons to expect it to escape the problems that have beset its predecessors. But its promise if it can do so is considerable. ${ }^{93}$

In spite of their mixed success, most government programs do push development in the right direction. Intensified and well-managed campaigns can provide some relief for rural underemployment, disseminate new agricultural techniques with greater rapidity, and reduce fertility slightly. And program activities themselves do eventually affect social structure. There is no doubt, for example, that the manifold agricultural development opportunities sketched out by Noazesh Ahmed (1976) if acted upon would, through the resulting economic change, radically alter rural social organization and probably also demographic behavior. 
But there remains the question of whether a programmatic approach is appropriate to Bangladesh's development predicament. Planners naturally tend to think of policy interventions in terms of inputs and outputs. For large development projects-flood control works, irrigation channels, industrial plants-this is the obvious way to assess feasibility and effectiveness. But with less centralized and less material activities-in particular, rural development and population control-maintaining a similar approach may distort emphasis and obscure important problems. We have argued that the critical policy issues lie in the area of local politics and social organization: how the interests of local factions and dominant families are pursued at the expense of the community as a whole, and how new political and material resources entering the rural society can serve to strengthen rather than erode this pattern. These structural issues are not merely "obstacles" to program design and operation, to be taken care of, as it were, at the stage of implementation; rather, they are the stuff of development itself and should be the main objects of policy.

\section{Strategy and Style}

In speculating on future prospects and government's part in them, we have deliberately avoided proposing any package of national policies. In a country whose national government has at best only limited purchase on local be:ıavior, most policy proposals would necessarily be moot. Suggestions, say, for strengthening cooperatives or for raising the legal marriage age would chiefly serve to expose these limitations. Bangladesh's experience with cooperatives is rivaled by that of few other countries, and continued failings in this area are not for want of understanding. And for marriage the legal minimum age for women already stands at 16 , in spite of which most are married at younger ages.94 In these final remarks, then, we confine ourselves to some general observations at the level of development strategy.

We would conclude from our analysis of Bangladesh's development and demographic situation that the country's present problems are less the result of not having some "right" combination of national policies than they are the consequence of a local societal structure that the government cannot quite reach. At its lowest levels the present administrative system mirrors the interests of the larger landowners and factional leaders. Thus, national government intentions and local economic and demographic realities typically work at cross purposes, impeding development results. An effective local administrative system able to harness powerful but presently conflicting social forces could do much to align individual behavior with the collective interest.

There are many ways in which effective local organization might be achieved, and several Asian models might be adapted to the special needs of Bangladesh. The recent experience of Indonesia under the "New 
Order" regime indicates one option: pressing government influence downward through society and designing local incentives to ensure that community interests (broadly defined, it is hoped) dominate. In Java, equal in area, population, and straitened circumstances to Bangladesh, incentives were imposed through a greatly strengthened administrative system; this has already yielded significant results in birth control, but it is still too early to assess its economic outcome or to weigh the long-run implications of the pervasive militarization of local government that underlies it. An alternative strategy, less harsh in some respects, harsher in others, is to limit administration to levels above the local community, making small territorial units responsible for their activities and relying on internal social pressures to bring individual behavior in line with the community interest. This strategy, similar to the one that operates in rural China below the commune level, would present problems in Bangledesh, where natural territorial units are weak and where current social change is, if anything, further eroding what territorial cohesion there is. Yet possibilities exist. The Chinese commune, a purely administrative unit, is roughly similar in size to the Bangladesh union. The commune's constituent villages (production brigades) and work groups (production teams) have at best only weak counterparts in Bangladesh at present, but it might prove possible to make either gram or para into solidary social units in a Bangladesh rural development strategy. ${ }^{95}$ Rural development models that involve less all-embracing organizational forms are also available. In the Bangladesh setting an option may be to build separate organizational bases to promote rapid growth of agricultural output and to ensure the rural landless of access to the economy.

Whatever means is chosen to reach down to the local level, effective social change undoubtedly requires a local setting much better able to afford security to the individual. A major theme of this paper has been that the interests of rural people in an uncertain and unhealthy environment are best served by behavior that guarantees some access to local product and that lowers risks. Attachment to patrons, exploitation of scarce local resources, adoption of roles of dependency, maintenance of family position through such means as purdah, and use of high fertility to insure against loss of land, children, or husband may yield access to the local distributive system; but above all they provide security. In aggregate, though, these modes of behavior act against collective interests and lend power and stability to the forces behind the present predicament. Much could be done to provide security at the local level-economically, through surer access to employment, credit, agricultural inputs, and irrigation; and demographically, through measures that prolong the lives of husband and children and reduce the gap in age between husband and wife. But more important than specific measures, if the new local system is to help break down the uncertainties that preserve 
high fertility and stifle individual initiative, it must provide a setting in which the individual looks to the community and his position within it for support and security, and less to the capricious favors of landlord or patriarch.

This need for effective structural organization has its counterpart in the industrial sector. Effective industrial development would call for a secure institutional environment for production, a need that goes much deeper than the usual demand for infrastructure.

The type of "intermediate level" strategy-directed at a level between the national government and the individual-that we see as essential to tackle the problems of Bangladesh is more a matter of structural change than of programmatic policy. Even with abrupt transfers of political power, it would be no short-term task. What is missing at present in Bangladesh that would greatly ease such a task is a coherent development style-an overall strategy that works toward a single purpose, that aligns interests in the same direction, and that cuts through conflicting objectives. The present array of loosely organized programs and ad hoc incentives is more a complex reaction to the pressures of urban interest groups, international agencies, and the rural power structure than a singleminded instrument of development.

The next years in Bangladesh could see the emergence of very different types of political regimes. Whatever the political color of the govemment, its success in development terms will likely be measured by its will and administrative reach to cut across local interests and influence economic and demographic behavior for the national good. If this does not come about, the present situation can continue for a while and population growth with it; but the possibility of real development will recede further into the future.

\section{Notes}

The authors wish to acknowledge the helpful comments of many colleagues on earlier drafts of this paper. In particular we would thank Monowar Hossain, Abu Abdullah, Shapan Adnan, Mohiuddin Alamgir, Mead Cain, Lincoln Chen, and other present or former staff members of the Bangladesh Institute of Development Studies; and John Bongaarts, Adrienne Germain, Mosharaff Hossain, Moni Nag, and Veena Thadani. We expect none of these colleagues to agree with all we have said, and some to disagree with much. A preliminary version of this paper was discussed at the Workshop on Country Reports on Population and Develop- ment, held in Bergen, Norway, September 1977 .

1. Moghul influence dates back to the thirteenth century. On the economy of pre-Muslim Bengal see Majumdar (1943), chapter 16. Later accounts are cited in N. Ahmad (1968), chapters 3-5.

2. Contributing to the disappearance of East Bengal's textile industry were the effects of the Great Bengal Famine (1769-76), followed by several years of devastating floods and famine in the 1780 s, the subsequent reorganization of the revenue collection system under the Permanent Settlement policy, and the 
high tariff imposed to protect British products. See N. Ahmad (1968), pp. 100-104, and M. A. Islam (1968). A small jute hand loom industry grew up for some decades in the nineteenth century, only to be supplanted by the Calcutta mills.

3. Historical data on city size are often suspect, but there is evidence of a substantial population decline in Dacca. Estimates are 200,000 in 1780 and about 70,000 in 1838. See N. Ahmad (1968), p. 104.

4. A UN estimate of material damage caused by the war was US $\$ 1.2$ billion; losses in the transport sector and in housing were especially severe. See Faaland and Parkinson (1976), p. 12, and N. Islam (1974). Other disruptions resulted from the departure of West Pakistani managers and civil servants.

5. For two accounts of policy during this period, before the dénoument became apparent, see Papanek (1967) and Haq (1963). Estimates of the transfer of resources from East to West Pakistan (highly dependent on exchange rate assumptions) range from US\$1.5 to 3.0 billion for the period 1947-69 (Faaland and Parkinson, 1976, pp. 7-8).

6. Historical productivity data are of course scarce, although indications can be drawn from relative constancy of cultivating techniques. Some studies of yields of the major crops from 1892 to 1947 are noted by N. Ahmad (1968), p. 191, who concludes: "Therefore, at best, productivity and yields may be regarded as constant, though betraying a tendency towards deterioration." Rice yields have risen only slightly in subsequent decades -about 15 percent between 1952 and 1974 (N. Ahmed, 1976, p. 20). Jute yields show no clear trend over the past 30 years.

7. Permanent Settlement gave revenue collectors proprietory rights over large estates (the zamindari system). See Tepper (1970), chapter 1, and M. A. Islam (1968) on the background and effects of this policy. It is of course easy to exaggerate the impact of the colonial intervention: The likely bias in this direction in both domestic and Western scholarship is noted by Morris and Stein (1961).

8. In the late nineteenth century a network of local councils (some nominally elected) was set up at the district level and below, but tumed out to be relatively powerless. The lowest level of council covered an area of several revenue villages, called a union. In 1919 the Village Self-Government Act established elected Union Boards with limited authority over local administration. See Tepper (1970) for a useful institutional history of preindependence Bangladesh.

9. See N. Ahmad (1968) and erRashid (1967) for comprehensive accounts of the physical geography of Bangladesh.

10. Of total cropped area about 80 percent is rice, $4-5$ percent jute, and 2.5 percent pulses. No other crop occupies more than 2 percent of the area (Bangladesh, Bureau of Statistics, 1977).

11. The Ganges-Kobadak Irrigation Project in Kushtia and Jessore districts, under construction since the 1950 s, is the most notable. A major problem with large-scale water control is that the topography dictates that necessary storage dams and canals would have to be located outside Bangladesh, in India and Nepal.

12. The Farakka Barrage, completed in 1975 , diverts water from the Ganges through its Indian distributary, the Hooghly, to flush the port of Calcutta. How much water will be diverted and what effect this will have on Bangladesh was an important point of contention between Bangladesh and India before an agreement was signed in 1977. The dispute was referred to the United $\mathrm{Na}$ tions in 1976: Diversion of Canges water in the dry season of that year, according to the Bangladesh government, "had unprecedented ecological and economic consequences. ... Irrigation facilities, particularly by pumps and shallow and even deep tubewells, have been hampered and 
pumps rendered inoperative. Some 400,000 acres of agricultural land have been affected.... River navigation was disrupted. Fishery, forestry and livestock resources have been severely depleted. The level of salinity has increased... seriously jeopardizing power and agricultural production." (United Nations, 1976)

13. General accounts of the demography of Bangladesh include $A$. Ahmed (1962) and M. R. Khan and A. R. Khan (1975). The earlier classic study of the subcontinent by Davis (1951) is characterized by a lack of detail on East Bengal.

14. From 1872 to 1921 population grew at an average yearly rate of 0.76 percent, mostly through natural increase. For comparison, the Indian growth rate for 1871-1921 was 0.36 percent per year. The higher rate recorded in Bangladesh may reflect census errors or more rapid natural increase; net migration into the region seems to have been neligible. See Davis (1951), pp. 27, 109-111, and, on migration specifically, M. R. Khan (1972b).

15. Death rates may have peaked to 50,60 , or more per thousand in times of severe famine or epidemic (Davis, 1951, chapter 5). The officially recorded death rate for 1918 , during the influenza epidemic, was 63 per thousand (Davis, p. 33). The most careful recent estimate (19.4, for 1961-74) comes from the 1974 Retrospective Survey (UK Ministry of Overseas Development, 1977). The official death rate series is given in the Statistical Pocket Book of Bangladesh 1978.

16. Improvements in transport and communication in themselves probably did as much to increase exports and facilitate speculation in food supplies as to even out price levels through interregional trade. From the late nineteenth century, however, government laissez faire attitudes toward famine were slowly replaced by a more activist policy (relief works, suspension of land revenue, and so on), so that as Bhatia (1967), p. 270, puts it, Famine was transformed into Food Problem.

17. Robinson (1967), pp. 14-15, and Davis (1951), chapter 5.
18. Birth rates in the range of 45 to 50 per thousand are given by the 1962-65 Population Growth Estimation project, by various other demographic surveys in the $1960 \mathrm{~s}$, and most recently by the 1974 Retrospective Survey, which estimated 48 per thousand. See M. R. Khan and A. R. Khan (1975) and UK Ministry of Overseas Development (1977). An estimate of 42 is made by Sirageldin, Norris, and Ahmad (1975), based on the 1968-69 National Impact Survey. (The discrepancies are not a product of shifts in age distributions since they also show up in estimates of total fertility.) See Potter (1977) and Blacker (1977) for discussions of some of the errors in these various results. Note that if, as seems likely, fertility was low and infant mortality high in the 1940s, birth rates may well have dropped below their long-run average in the late 1960s as the small 1940s cohort passed through its peak reproductive years.

19. In Partition it is estimated that 2.6 million Hindus emigrated from the region while 700,000 Muslims immigrated. During the 1971 war some 7 to 10 million people (chielly Hindus-probably over half of Bangladesh's Hindu population) fled to India, with perhaps a million of them remaining in India after peace was restored. There was also a much smaller exodus of Hindus at the time of the 1965 Indo-Pakistan War. See M. R. Khan (1972a, 1972b). Khan speculates that net migration over the 1961-72 period could have amounted to more than 2 million. But even that number is only a tenth of the actual population growth in Bangladesh in that period.

20. See N. Ahmad (1968), pp. 300 303.

21. Caution is needed in tracing the recent population growth differentials to new activity in agriculture. The data are not fully reliable (the 1974 census in particular was taken under difficult circumstances), and the convulsive migrations of the early 1970 s preclude any simple interpretation of growth rates.

22. On embankments and their im- 
pact and on the forest ecology, see $\mathrm{N}$. Ahmad (1968), p. 37 and chapter 7. Ecological problems created by the new rice technology include increased risk of crop disease and pest damage with varietal specialization, eutrofication from heavy fertilizer use, harmful residues of pesticides and weedicides, and the impact of deep tubewells on the water table.

23. See Faaland and Parkinson (1976), chapter 2. The Bureau of Statistics index of real wages $(1969-70=100)$ fell steadily from 108 in the mid-1960s to 65 in the early 1970s (and to 49 in the famine year 1974-75); in 1976-77 it had risen to 71 (Statistical Pocket Book of Bangladesh 1978).

24. Gustav Ranis (1974), p. 855, is more hopeful than we on the prospects for export processing zones, leading in turn to decentralized labor-intensive industrial production for export: "It is by no means unrealistic to expect Bangladesh to ultimately become an important competitor in this area, a field vacated by Taiwan, Korea, Singapore, Hong Kong, etc. whose wages are rising as a consequence of the exhaustion of the labor surplus."

25. The World Bank report is unpublished; its findings are referred to by Faaland and Parkinson (1976), p. 132.

26. Area under high-yielding varieties had reached only 15 percent of rice cropped area by 1975-76 (Bangladesh, Bureau of Statistics, 1977). Inputs have recorded rapid increases, but from a very small base. Data for the early 1970s show more than 30,000 low-lift pumps in use, a tenfold increase over a decade, and a cumulative total of some 5,000 tubewells (N. Ahmed, 1976, p. 25). Each pump or well on average might irrigate 15 to 20 hectares. About 6.5 percent of cultivated area is now irrigated by low-lift pumps, 1.2 percent by tubewells. Altogether, total cropped area as a percentage of cultivated area has grown from 127 percent in the early 1960 s to nearly 150 percent at present. Fertilizer consumption (in terms of nutrient value) quadrupled in the decade
1965-74 (Bangladesh, Bureau of Statistics, 1977).

27. Access to land is defined more precisely by effective landholding-that is, land owned and cultivated, adjusted for the amounts mortgaged and sharecropped (in or out). See Wood (1976), p. 69. Noncultivator occupations are still only a small fraction of the rural labor force. Fishing and livestock husbandry are typically secondary occupations within farm or agricultural laborer families. Nonagricultural occupations (chiefly commerce and services) made up 17 percent of the rural labor force in 1964, according to the Master Survey of Agriculture of that year.

28. Data on the agricultural labor force and distribution of holdings are taken from Alamgir (1977), Table 6, and the 1968 Master Survey of Agriculture. The categorization of farm families is of course highly schematic, ignoring the important considerations of family size, lifecycle stage, local agricultural conditions, and nonagricultural income, all of which would influence the economic significance of a particular size of landholding. Many villages in the core areas of the country have no holdings above 3 hectares; for local purposes the "surplus" cutoff should be lower.

29. Cultivated area grew by $\mathbf{5 0}$ percent in the first four decades of this century, but has changed little since the 1940s. Average size of holding is considered to have diminished over the same earlier period ( N. Ahmad, 1968, pp. 184187, 195). Cain (1977) estimates a subsistence holding at 0.65 hectares for an average household in an average year.

30. In fact, Table 2 suggests that there has been some squeezing out of small farms. There is also evidence of a rising proportion of land operated by tenants-from 18 percent of farm area in 1960 to 25 percent in 1974 (Alamgir, 1975 , p. 269 ). On the actual procedures of land transfers and their frequency by size of holding, see Alamgir ( 1977), chapter 4. Bertocci (1970), chapter 4, discusses the economics of land mortgaging and foreclosure. Mead Cain (personal 
communication) notes that the process of upward economic mobility, although less common than its opposite, does occur: Even originally landless agricultural workers, by effort and luck, can sometimes ascend the ladder.

31. The available data on landlessness do not constitute a consistent series. The 1964 Master Survey of Agriculture estimated the proportion at 14 percent of the agricultural labor force, whereas the SIDA/ILO Report a decade later recorded more than double this proportion (Abdullah, Hossain, and Nations, 1974). The 1951 and 1961 census estimates were 14 percent and 17 percent (Census of Pakistan 1961, vol. 2); the 1977 Land Occupancy Survey gives 27 percent (Statistical Pocket Book of Bangladesh 1978, p. 121 ).

32. Based on the census labor force data and a smoothed series of proportions landless. For the male labor force considered alone, the 1961-74 growth would have been about 4 million, with 3 to 3.5 million taken up by increasing landlessness.

33. Findings from the Dacca University Village Study Group (Adnan et al., 1977).

34. In addition they may be able to place one or more members in secure nonagricultural occupations, as clerks, teachers, and so on. See M. A. Huq (1976), chapters 4 and 7, for a discussion of class differences in occupational diversification among peasant families.

35. Cain (1977), pp. 206-207, describes the advantage to landholding families of providing most or all of their cultivating labor themselves rather than hiring workers: Family labor reduces the often critical cash-flow problems, especially at harvest time, and does not need the same supervision.

36. The growth of migrant agricultural labor in Bangladesh is a particularly important phenomenon. On its effect on the local labor market see Wood (1976), pp. 152-156.

37. The information on social organization presented here and assembled in
Table 3 is an amalgam derived chiefly from A. Islam (1974), Bertocci (1970), and the working papers of the Dacca University Village Study Group.

38. Normatively, a bari would comprise a man, his wife and sons, the wives of married sons, grandchildren, unmarried daughters, and perhaps widowed sisters. A bari's land, however, may already have been divided among its constituent households even before the death of the head, and conflict among bari members, sometimes leading to litigation, is fairly common.

39. See, for example, Dacca University Village Study Group (1975).

40. The gram or "local village," relevant in discussing social organization, does not always correspond to the mauza, a revenue unit also called a village that was set up in the nineteenth century, or to the more recently defined "census village" created for statistical purposes. Bertocci (1976), p. 161, cites 1963 data for the Kotwali thana (see note 47) of Comilla district showing 463 gram (averaging 340 persons), whereas there were about 200 mauza and 250 census villages. Investigations preceding the 1975 World Fertility Survey, however, found frequent coincidence between the administrative and socially accepted units.

41. A. Islam (1974), p. 75. The residual identification, however, can be important on occasions: Conflicts or feuds between villages are not unknown.

42. See N. Ahmad (1956) for a region-by-region description of settlement patterns in Bangladesh. Nucleated villages are the rule in the moribund delta areas.

43. The diminishing importance of kinship groups and shamaj is discussed by Abdullah, Hossain, and Nations (1976), p. 217; Tepper (1976), p. 36; and Wood (1976), pp. 147-149. On shifts in agricultural arrangements with commercialization see Alamgir (1975).

44. Wood (1976), pp. 154-156. Many such people also end up among the urban homeless: See Farouk (1976) for a description of the process of extrusion 
from the countryside based on individual case histories.

45. An elaborate investigation into rural socioeconomic structures and change in Bangladesh, now under way at the Bangladesh Institute of Development Studies, should substantially fill out our information in this important area.

46. See in particular Adnan (1976) and Dacca University Village Study Group (1975).

47. Unions have an average area of about $35 \mathrm{~km}^{2}$. The next higher administrative unit, the thana, covers about 10 unions, with an average population of 160,000 and average area of $300 \mathrm{~km}^{2}$.

48. Sobhan (1968), pp. 77-88; Tepper (1970), p. 217; and A. Islam (1974). Rahman (1962) gives a systematic account of the Basic Democracies scheme of 1959 , which set up the union councils and similar committees at the thana and higher administrative levels. Union council members represent electoral wards, which do not necessarily coincide with any social unit-sometimes spanning several villages, in other cases intersecting them.

49. "[The well-off farmer] can invest his surplus money without any risk or labor by just loaning it to his neighbors who are small farmers. Each year he gets almost cent per cent return and his principal still remains unpaid. If he saves some paddy, he can loan it from harvest to harvest and get back one and a half maunds or more for one maund. So, when this surplus farmer is told that he should use better methods, better seeds or better fertilizers for more production from his land, he is not interested." (A. Abdullah, 1976 , p. 89 , quoting a Comilla report of 1963)

50. The "Comilla experiment" and its various progeny have an extensive literature. For assessments from various standpoints see A. H. Khan (1971), Raper (1970), and Abdullah, Hossain, and Nations (1974).

51. On the Rural Public Works Pro- gramme see Thomas (1968) and Sobhan (1968).

52. Abdullah, Hossain, and Nations (1976) assess these possible consequences.

53. Data from 1974 census. See Miranda (1977). Two other urban areas exceeded 100,000 population: Mymensingh and Rajshahi.

54. Alamgir (1973), p. 28.

55. On marriage ages see Census of Pakistan 1961, vol. 2, p. III-10 and Elahi (1974), p. 5. The 1968-69 Impact Survey estimated the median age at marriage of a sample of married women under age 55 to be 13.2 years, with three-quarters married before turning 14 and only 5 percent still single by age 16 (Pakistan Population Planning Council, n.d., p. 21). Higher figures for the (singulate) mean age at marriage are obtained in the 1974 Retrospective Survey: 16.5 years for women, 24.9 for men. See UK Ministry of Overseas Development (1977), p. 58, in which evidence for recent increases is also discussed. See also note 71 .

56. The 1974 Retrospective Survey estimated total fertility at 7.1. See also note 18.

57. See Cain (1977) for an empirical study of the economic contribution of children to a family.

58. The evidence on food availability and nutrition is reviewed by Chen and Chaudhury (1975). Alamgir (1974), p. 784 , calculates that in the 1960 s a proportion fluctuating between 50 percent and 70 percent of the population fell below a "minimum" level of living corresponding to a daily intake of 2,100 calories and $58 \mathrm{gm}$ protein. (On the trend in real wages, see note 23.)

59. Information from L. C. Chen (personal communication). Cause - of death data are collected as part of the statistical program of the Cholera Research Laboratory in Matlab thana, but have not yet been adequately analyzed. See Curlin, Chen, and Hussain (1976), Table 7 for the Matlab data as presently 
classified. National cause-of-death estimates given by Robinson (1967), p. 31 , for about 1960 appear to substantially overstate the present contribution of malaria and maternal mortality, and to understate diarrheal diseases.

60. A recent Cholera Research Laboratory survey in a rural area on knowledge of disease transmission found, for example, that less than 5 percent of respondents believed that spread of diarrhea and dysentery was related to polluted water or bad food (Cholera Research Laboratory, 1977, p. 23). In 1969 it was estimated that two-thirds of unions in rural Bangladesh had no clinic or dispensary; on average there was one doctor per 50,000 persons, one paramedical worker per 5,000 (Awan, 1969, pp. 73-85). Much health care is in the hands of homeopaths, hakims, and other traditional healers.

61. Cain (1978). As could be expected, infant mortality shows comparatively little class difference, since infants are afforded fairly uniform nutritional and immunological protection by breastfeeding.

62. See Jahan (1975) for an overview of sex differentiaton in the laborforce and occupational discrimination faced by women. T. Abdullah (1974) gives useful descriptive material on women's place in society, their duties, marriage, purdah, and so on. For a wide bibliography on women in Bangladesh see Germain (1977).

63. See Chen and Ghuznavi (n.d.) and T. Abdullah and Zeidenstein (1977) for interesting case material on the threat of divorce and death of children and husband. In the 1974 Retrospective Survey, the proportion of divorced among ever-married women peaks at 3.5 percent at ages 20 to 24 , tailing off in later years.

64 . The mortality regimes that underlie the average duration of marriage shown in Figure 3 imply that in the present decade about 17 percent of ever-married women would be widowed by age 35 and 30 percent by age 45 ; in the 1930s the corresponding proportions would have been 33 percent and 50 percent.
65. On this practice see, for example, Bertocci (1970), p. 124.

68. T. Abdullah (1974).

67. Urban fertility is 7 percent lower than rural; the greatest fertility difference among divisions is 5 percent (UK Ministry of Overseas Development, 1977, p. 79). Cain and DeVries-Baastiens (1978), tables 5 and 6, assemble 1968-69 Impact Survey data indicating almost no fertility differences between families with "adequate" and "inadequate" living conditions, or between families with and without agricultural land. For similar findings on landholding differentials see Aird (1956), pp. 271-278, and Stoeckel and Choudhury (1973), p. 123-the latter giving "desired" rather than attained family size data. A small positive differential by education at its lower levels is found in the 1974 Retrospective Survey (UK Ministry of Overseas Development, 1977, chapter 5 ). On urban middle-class fertility see Duza (1974), pp. 69, 81, for some relevant survey data.

68. Based on figures from the Matlab registration area in Comilla district, the only source of data on year-to-year variations. The crude birth rate averaged $\mathbf{4 4 . 8}$ per thousand over 1966-76, excluding 1972 and 1975; birth rates for the latter two years were 41.8 and 27.6 (Cholera Research Laboratory, 1977, Table 1).

69. The estimate of mean lactational amenorrhea in Bangladesh is given by Chen et al. (1974), p. 296. The fertility impact is calculated using the formulas and ceteris paribus assumptions of Bongaarts (1978). If lactation dropped to US levels, fertility could be raised 75 percent.

70. See Knodel (1977).

71. A more significant effect of poor nutrition is to delay menarche. Recent research suggests, however, that better nutrition in Bangladesh would at most raise fertility by around 5 percent. See Bongaarts and Delgado (1977) and Mosley (1977). It has been speculated that the apparent recent increase in age at marriage reflects the delayed menarche of 
girls who experienced the food crises of the early 1970 s, since onset of menarche often triggers marriage (Cholera Research Laboratory, 1977, p. 40).

72. Potential fertility lost by death of the wife by definition does not enter the measure of total fertility, hence is not considered here.

73. Chen et al. (1974), p. 296.

74. See Afzal (1967), p. 61, and UK Ministry of Overseas Development (1974). An earlier village demographic study by Aird (1956), p. 157, concluded that between 96 and 98 percent of women are initially capable of procreation.

75. Secondary sterility shows some uniformity across different populations. Henry's data for European populations (perhaps a lower bound for Bangladesh) average 3 percent of married women sterile at age 20, $\theta$ percent at age 25,10 percent at age 30,16 percent at age 35 and 31 percent at age 40 (Henry, 1961, p. 85 ).

76. Sirageldin, Hossain, and Cain (1975), p. 6. A slightly higher percentage (6.4) had ever used contraception. Induced abortion is thought to be almost nonexistent (Chen et al., 1974, p. 279).

77. Sirageldin, Hossain, and Cain (1975), p. 24, conclude from analysis of the Impact Survey: "Even if we take all current use and expected future use, based on reported intentions, this total expected demand was and is not large enough to generate the desired fertility reductions in Bangladesh."

78. The experiment, begun in 1975 , covers a population of 125,000 with a similar-sized control group. A user rate of 10 percent might lead to a drop of perhaps 5 points in the birth rate, say to around $\mathbf{4 0}$ per thousand. It would be difficult, however, to replicate such a program on a wide scale. See A. R. Khan and Huber (1977) and Cholera Research Laboratory (1977), pp. 36-37.

79. Duza (1974), p. 82, cites data from a 1974 survey of male villagers in rural Chittagong: 86 percent of respond- ents thought the country was now in worse condition than in the past, and 80 percent considered their own condition to be less happy than that of their forefathers.

80. The argument is developed by Cain (1978), who finds evidence of the "crisis management function" provided by depth in the household labor force.

81. The term is Abu Abdullah's (personal communication).

82. Of ever-married women in their 40 s in 1969,13 percent had no living sons (calculated from Impact Survey data). The corresponding percentage for women at this lowest economic level may well exceed twice that Ggure.

83. From this description it might seem that no increase in female marital age could be expected. But forces that would tend to raise this age can be detected: lessening strength of the patriarchal family as assets are diluted ( control of a son's behavior is maintained by promise of inheritance rather than filial piety) and gradual raising of women's status in the family.

84. Baldwin (1977) contrasts a population projection assuming constant mortality and fertility at current levels with one in which there are an additional 500,000 disaster fatalities annually, and shows that the population attained by the year 2000 in the former case ( 156 million) is reached only six years later in the latter case.

85. India's industrial production averaged 6.1 percent annual growth over 1951-7.3 (Veit, 1976, p. 75).

86. The index of industrial production in Bangladesh on a base $1970=100$ has recorded the following recent changes: 1974,$90 ; 1975,81 ; 1976,87 ; 1977,97$ (Statistical Pocket Book of Bangladesh 1978 , p. 178).

87. In a recent survey of union council members, M. Rashiduzzaman (personal communication) found evidence of a "new" elite beginning to emerge in addition to the landed gentry-professional 
people, local contractors, and other small businessmen.

88. Based on Matlab data given by Chaudhury and Curlin (1975) and Miranda (1977), on average in a village of 500 people, perhaps 5 persons a year would move to a town and 2 or 3 return. The 1968-69 National Impact Survey found that 25 percent of married women villagers had ever visited a town, and 15 percent had done so in the past 12 months (Pakistan Population Planning Council, n.d., p. 36). The figures for men would, of course, be greater.

89. See Bangladesh Rural Advancement Committee (1976) and Chen and Ghuznavi (n.d.).

90. Using Cain's data (1977), this would happen if rural wages fell by 30 percent.

91. For an account of family planning program activities see Bangladesh, Population and Nutrition Projects Department (1975). A broad criticism of the program is contained in Demeny (1975).
92. See, for example, M. Ahmed (1977a, 1977b) and Haque et al. (1977). The latter gives a brief report on the socalled Rangpur Self-reliant Movement, which achieved remarkable and widely publicized results in organizing peasants for a variety of development objectives (including population stabilization) in a single village (Kunjipukur) in Rangpur district, and which has subsequently spread to other villages in the area.

93. The Swanirvar movement takes much of its impetus from the isolated examples mentioned in the previous note. See Alamgir (1977), chapter 5, for a description and skeptical assessment.

94. See Bangladesh, Population Control and Family Planning Division (1976), p. 12.

95. Signs of interest in this general policy approach include the discussion of "compulsory cooperatives" in the last months of the Mujib administration, and the still-developing Swanirvar movement, mentioned earlier.

\section{BIBLIOGRAPHY}

Abdullah, Abu. 1976. "Land reform and agrarian change in Bangladesh." Bangladesh Development Studies 4, no. 1: 67-99.

- Mosharaff Hossain, and Richard Nations. 1974. SIDA/ILO Report on Integrated Rural Development Programme, Bangladesh. Dacca.

1976. "Agrarian structure and the IRDP-preliminary considerations." Bangladesh Development Studies 4, no. 2: 209-266.

Abdullah, Tahrunessa Ahmed. 1974. "Village women as I saw them." Mimeo, The Ford Foundation, Dacca. (Originally published in 1966.)

-, and Sondra Zeidenstein. 1977. "Rural women in development." In Role of Women in Socio-Economic Development in Bangladesh. Dacca: Bangladesh Economic Association.

Adnan, Shapan. 1976. "Land, power and violence in Barisal villages," Dacea University Village Study Group, Working Paper no. 6.

et al. 1975. "The preliminary findings of a social and economic study of four Bangladesh villages." Dacca University Studies 23 (June): 111-127.

1977. "Differentiation and class structure in village Shamraj," Dacca University Village Study Group, Working Paper no. 8. 
Afzal, Mohammed. 1967. "The fertility of East Pakistan married women." In Studies in the Demography of Pakistan, ed. W. C. Robinson. Karachi: Pakistan Institute of Development Economics.

Ahmad, Nafis. 1956. "The pattem of rural settlement in East Pakistan." Geographical Review 46, no. 3: 388-398.

1968. An Economic Geography of East Pakistan, 2nd ed. London: Oxford University Press.

Ahmed, A. S. M. Mohiuddin. 1962. "The population of Pakistan: Past and present." Ph.D. dissertation, Duke University.

Ahmed, Manzoor. 1977a. "BRAC: Building human infrastructure to serve the rural poor." Mimeo, Intemational Council for Educational Development, Essex, Conn.

- 1977b. "The Savar Project: Meeting the rural health crisis in Bangladesh." Mimeo, International Council for Educational Development, Essex, Conn.

Ahmed, Noazesh. 1976. Development Agriculture of Bangladesh. Dacca: Bangladesh Books International.

Aird, John S. 1956. "Fertility levels and differentials in two peasant villages." $\mathrm{Ph} . \mathrm{D}$. dissertation, University of Michigan.

Alamgir, Mohiuddin. 1973. "Approaches towards research methodology on problems of urbanization in Bangladesh." Research Report no. 15 (new series), Bangladesh Institute of Development Economics, Dacca.

- 1974. "Some analysis of distribution of income, consumption, savings, and poverty in Bangladesh." Bangladesh Development Studies 2: 737818.

1975. "Some aspects of Bangladesh agriculture: Review of performance and evaluation of policies." Bangladesh Development Studies 3:261-300.

-1 1977. Bangladesh: Acme of Below Poverty Level Equilibrium Trap. Dacca: Bangladesh Institute of Development Studies.

Awan, Akhtar. 1969. The System of Local Health Services in Rural Pakistan. Lahore: Public Health Association of Pakistan.

Baldwin, C. Stephen. 1977. "Catastrophe in Bangladesh: An examination of alternative population growth possibilities 1975-2000." Asian Survey 17: 345-357.

Bangladesh. Bureau of Statistics. 1977. Yearbook of Agricultural Statistics of Bangladesh 1975-76. Dacca.

Bureau of Statistics. 1978. Statistical Pocket Book of Bangladesh 1978. Dacea.

Population and Nutrition Projects Department. 1975. "The population program of the Government of Bangladesh: A sector review." Dacca.

- Population Control and Family Planning Division. 1976. “An outline of the National Population Policy of Bangladesh." Mimeo.

Bangladesh Rural Advancement Committee (BRAC). 1976. "Pachbarol's destitute women's cooperative." BRAC Newsletter 1, no. 6 (NovemberDecember).

Bertocci, Peter J. 1970. "Elusive villages: Social structure and community orga- 
nization in rural East Pakistan." Ph.D. dissertation, Michigan State University.

1976. "Rural development of Bangladesh." In Rural Development in Bangladesh and Pakistan, ed. Robert D. Stevens, Hamza Alavi, and Peter J. Bertocci. Honolulu: University Press of Hawaii.

Bhatia, B. M. 1967. Famines in India: A Study of Some Aspects of the Economic History of India (1860-1965), 2nd ed. Bombay: Asia Publishing House.

Blacker, J. G. C. 1977. "Dual record demographic surveys: A re-assessment." Population Studies 31: 585-597.

Bongaarts, John. 1978. “A framework for analyzing the proximate determinants of fertility." This volume.

—, and Hernan Delgado. 1977. "Effects of nutritional status on fertility." In Proceedings of the International Population Conference Mexico, vol. 1. Liege: International Union for the Scientific Study of Population.

Cain, Mead. 1977. "The economic activities of children in a Bangladesh village." Population and Development Review 3, no. 3 (September): 201-227.

1978. "Economic class, economic mobility and the developmental cycle of households: A case study in rural Bangladesh." Paper presented to the annual meeting of the Population Association of America, Atlanta, Georgia.

and Woutje DeVries-Baastiens. 1976. "Household structures and fertility in Bangladesh." Paper presented at the annual meeting of the Population Association of America, Montreal, 28 April-1 May.

Chaudhury, Rafiqul Huda, and George C. Curlin. 1975. "Dynamics of migration in a rural area of Bangladesh." Bangladesh Development Studies 3, no. 2: 181-230.

Chen, L. C., ed. 1973. Disaster in Bangladesh: Health Crisis in a Developing Nation. New York: Oxford University Press.

et al. 1974. "A prospective study of birth interval dynamics in rural Bangladesh." Population Studies 28: 277-298.

- - and Rafiqul Huda Chaudhury. 1975. "Demographic change and food production in Bangladesh, 1960-74." Population and Development Review 1, no. 2 (December): 201-227.

Chen, Marty, and Ruby Ghuznavi. n.d. "Women in food-for-work: The Bangladesh experience." Unpublished paper.

Cholera Research Laboratory. 1977. Annual Report 1977. Dacca.

Curlin, G. T., L. C. Chen, and S. B. Hussain. 1976. "Demographic crisis: The impact of the Bangladesh civil war (1971) on births and deaths in a rural area of Bangladesh." Population Studies 30: 87-105.

Dacca University Village Study Group. 1975. "Social structure and implications for resource allocation in a Chittagong village." Working Paper no. 3.

Davis, Kingsley. 1951. The Population of India and Pakistan. Princeton: Princeton University Press.

Demeny, Paul. 1975. "Observations on population policy and population program in Bangladesh." Population and Development Review 1, no. 2 (December) : 307-321. 
Duza, M. Badrud. 1974. "Cultural consequences of population change in Bangladesh." Paper prepared for the seminar on Cultural Consequences of Population Change, 14-17 August 1974, Bucharest, Romania.

Eaton, Joseph W., and Albert J. Mayer. 1953. "The social biology of very high fertility among the Hutterites." Human Biology 25: 206-264.

Elahi, K. M. 1974. "Spatial distribution of population structures in Bangladesh." In Studies in Bangladesh Geography, ed. A. F. M. Kamaluddin. Dacca: Bangladesh National Geographical Association.

er-Rashid, Haroun. 1967. East Pakistan: A Systematic Regional Geography and Its Development Planning Aspects, 2nd ed. Lahore: Ghulam Ali.

Faaland, Just, and J. R. Parkinson. 1976. Bangladesh: The Test Case for Development. London: Hurst.

Farouk, A. 1976. The Vagrants of Dacca City: A Socioeconomic Survey. Dacca: Bureau of Economic Research, Dacca University.

Germain, Adrienne. 1977. "Notes on indicators of women's status and roles." Paper prepared for the Workshop on Country Reports on Population and Development, Bergen, Norway, September 1977.

Haq, Mahbub ul. 1963. The Strategy of Economic Planning: A Case Study of Pakistan. Karachi: Oxford University Press.

Haque, Wahidul et al. 1977. "Towards a theory of rural development" Development Dialogue no. 2.

Henry, L. 1961. "Some data on natural fertility." Eugenics Quarterly 8: 81-91.

Huq, M. Ameerul, ed. 1976. Exploitation and the Rural Poor: A Working Paper on the Rural Power Structure in Bangladesh. Comilla: Bangladesh Academy for Rural Development.

Islam, A. K. M. Aminul. 1968. "Changes in cropping patterns in East Pakistan." Oriental Geographer 12: 1-25.

-1974. A Bangladesh Village, Conflict and Cohesion: An Anthropological Study of Politics. Cambridge, Mass.: Schenkman.

Islam, Nurul. 1974. "The state and prospects of the economy." In The Economic Development of Bangladesh within a Socialist Framework, ed. E. A. G. Robinson and K. B. Griffin. London: Macmillan.

Jahan, Rounaq. 1975. "Women in Bangladesh." In Women for Women: Bangladesh 1975. Dacca: University Press.

Khan, Akhter Hameed. 1971. Tour of Twenty Thanas, 21-12-1970 to 28-1-1971. Comilla: Bangladesh Academy of Rural Development

Khan, Atiqur R., and Douglas H. Huber. 1977. "Household distribution of contraceptives in Bangladesh-rural experience." Paper presented at the Regional Conference on Village and Household Availability of Contraceptives, Tunis, 27-30 March 1977.

Khan, Masihur Rahman. 1972a. "Bangladesh population during the first Five Year Plan period (1972-1977): A guestimate." Research Report no. 6 (new series), Bangladesh Institute of Development Economics, Dacca. 1972b. "Migration within and across the boundaries of East and West Pakistan, 1901-61." Ph.D. dissertation, Australian National University, Canberra.

and Aminur Rohman Khan. 1975. "Demographic processes in Bangladesh." Country background paper for the Seminar on Population 
Policy, Bangladesh, 15-21 May 1975. Population Study Centre, Bangladesh Institute of Development Studies, Dacca.

Knodel, John. 1977. "Breast-feeding and population growth." Science 198: 11111115.

Majlis, Daud. 1977. “A basketful of hope." Far Eastern Economic Review. (23 September) : 22-25.

Majumdar, R. C., ed. 1943-48. History of Bengal, 2 vols. Vol. 1, Dacca, 1943; Vol. 2, Calcutta, 1948.

McCord, Colin. 1976. "What's the use of a demonstration project?" Mimeo, The Ford Foundation, Dacca. (Report no. 45)

Miranda, Armindo. 1977. "Les migrations au Bangladesh." Population no. 2: 448-459.

Morris, Morris D., and Burton Stein. 1961. "The economic history of India: A bibliographic essay." Journal of Economic History 21: 179-207.

Mosley, Henry. 1977. "The effects of nutrition on natural fertility." Paper presented at the Seminar on Natural Fertility, Institut national d'Etudes demographiques, Paris, March 1977.

Pakistan Population Planning Council. n.d. National Impact Survey Report. Lahore, c. 1970.

Papanek, Gustav F. 1967. Pakistan's Development: Social Goals and Private Enterprise. Cambridge, Mass.: Harvard University Press.

Potter, J. E. 1977. "Problems in using birth-history analysis to estimate trends in fertility." Population Studies 31: 335-364.

Rahman, A. T. R. 1962. Basic Democracies at the Grass Roots. Comilla: Pakistan Academy for Village Development.

Ranis, Gustav. 1974. "Brief reflections on the central issues of policy in Bangladesh." Bangladesh Development Studies 2: 839-856.

Raper, Arthur F. 1970. Rural Development in Action: The Comprehensive Experiment at Comilla, East Pakistan. Ithaca, N.Y.: Cornell University Press.

Robinson, Warren C. 1967. "Recent mortality trends in Pakistan." In Studies in the Demography of Pakistan, ed. W. C. Robinson. Karachi: Pakistan Institute of Development Economics.

Sirageldin, Ismael, Monowar Hossain, and Mead Cain. 1975. "Family planning in Bangladesh: An empirical investigation." Bangladesh Development Studies 3, no. 1: 1-26.

-, D. Norris, and M. Ahmad. 1975. "Fertility in Bangladesh: Facts and fancies." Population Studies 29: 207-215.

Sobhan, Rehman. 1968. Basic Democracies, Works Programme and Rural Development in East Pakistan. Dacca: Oxford University Press.

Stoeckel, John, and Mogbul A. Choudhury. 1973. Fertility, Infant Mortality and Family Planning in Rural Bangladesh. Dacca: Oxford University Press.

Tepper, Elliot. 1970. "Rural development and administration in East Pakistan." Ph.D. dissertation, Duke University.

1976. "The administration of rural reform: Structural constraints." In Rural Development in Bangladesh and Pakistan, ed. Robert D. Stevens, Hamza Alavi, and Peter J. Bertocci. Honolulu: University Press of Hawaii. 
Thomas, John. 1968. "The Rural Public Works Programme and East Pakistan's development." Ph.D. dissertation, Harvard University.

UI Ministry of Overseas Development. 1977. Report on the 1974 Bangladesh Retrospective Suroey of Fertility and Mortality, ed. J. G. C. Blacker. London and Dacca.

United Nations. General Assembly. 1976. "Request for the inclusion of a supplementary item in the agenda of the Thirty-first Session: Question of unilateral diversion of waters of the international river Ganges, in contravention of all international laws and regulations and tradicional usages and in violation of solemn pledges on the use of such waters." Letter dated 26 August 1976 from the Permanent Representative of Bangladesh to the United Nations, addressed to the Secretary-General. UN document A/31; 195/Add. 1. New York.

Veit, Lawrence A. 1976. India's Second Revolution: The Dimensions of Development. New York: McGraw-Hill.

Wood, Geoffrey D. 1976. "Class differentiation and power in Bondokgram: The minifundist case." In Exploitation and the Rural Poor: A Working Paper on the Rural Power Structure in Bangladesh, ed. M. Ameerul Huq. Comilla: Bangladesh Academy for Rural Development. 